\title{
Overview of the Focused Isoprene eXperiment at the California Institute of Technology (FIXCIT): mechanistic chamber studies on the oxidation of biogenic compounds
}

\author{
T. B. Nguyen ${ }^{1}$, J. D. Crounse ${ }^{1}$, R. H. Schwantes ${ }^{1}$, A. P. Teng ${ }^{1}$, K. H. Bates ${ }^{2}$, X. Zhang ${ }^{1}$, J. M. St. Clair ${ }^{1}$, W. H. Brune ${ }^{3}$, \\ G. S. Tyndall ${ }^{4}$, F. N. Keutsch ${ }^{5}$, J. H. Seinfeld ${ }^{2,6}$, and P. O. Wennberg ${ }^{1,6}$ \\ ${ }^{1}$ Division of Geological and Planetary Sciences, California Institute of Technology, Pasadena, California, USA \\ ${ }^{2}$ Division of Chemistry and Chemical Engineering, California Institute of Technology, Pasadena, California, USA \\ ${ }^{3}$ Department of Meteorology, Pennsylvania State University, University Park, Pennsylvania, USA \\ ${ }^{4}$ Atmospheric Chemistry Division, National Center for Atmospheric Research, Boulder, Colorado, USA \\ ${ }^{5}$ Department of Chemistry, University of Wisconsin - Madison, Madison, Wisconsin, USA \\ ${ }^{6}$ Division of Engineering and Applied Science, California Institute of Technology, Pasadena, California, USA
}

Correspondence to: T. B. Nguyen (tbn@ caltech.edu)

Received: 27 July 2014 - Published in Atmos. Chem. Phys. Discuss.: 25 August 2014

Revised: 10 November 2014 - Accepted: 20 November 2014 - Published: 19 December 2014

\begin{abstract}
The Focused Isoprene eXperiment at the California Institute of Technology (FIXCIT) was a collaborative atmospheric chamber campaign that occurred during January 2014. FIXCIT is the laboratory component of a synergistic field and laboratory effort aimed toward (1) better understanding the chemical details behind ambient observations relevant to the southeastern United States, (2) advancing the knowledge of atmospheric oxidation mechanisms of important biogenic hydrocarbons, and (3) characterizing the behavior of field instrumentation using authentic standards. Approximately 20 principal scientists from 14 academic and government institutions performed parallel measurements at a forested site in Alabama and at the atmospheric chambers at Caltech. During the 4 week campaign period, a series of chamber experiments was conducted to investigate the dark- and photo-induced oxidation of isoprene, $\alpha$-pinene, methacrolein, pinonaldehyde, acylperoxy nitrates, isoprene hydroxy nitrates (ISOPN), isoprene hydroxy hydroperoxides (ISOPOOH), and isoprene epoxydiols (IEPOX) in a highly controlled and atmospherically relevant manner. Pinonaldehyde and isomer-specific standards of ISOPN, ISOPOOH, and IEPOX were synthesized and contributed by campaign participants, which enabled explicit exploration into the oxidation mechanisms and instrument responses for these important atmospheric compounds. The present overview de-
\end{abstract}

scribes the goals, experimental design, instrumental techniques, and preliminary observations from the campaign. This work provides context for forthcoming publications affiliated with the FIXCIT campaign. Insights from FIXCIT are anticipated to aid significantly in interpretation of field data and the revision of mechanisms currently implemented in regional and global atmospheric models.

\section{Introduction}

\subsection{Background}

Biogenically produced isoprenoids (hydrocarbons comprised of $\mathrm{C}_{5} \mathrm{H}_{8}$ units) have global emission rates into the atmosphere surpassing those of anthropogenic hydrocarbons and methane (Guenther et al., 1995, 2012). The biogenic carbon emission flux is dominated by isoprene $\left(\mathrm{C}_{5} \mathrm{H}_{8}\right)$ and monoterpenes $\left(\mathrm{C}_{10} \mathrm{H}_{16}\right)$, which account for approximately 50 and $30 \%$ of the $\mathrm{OH}$ reactivity over land, respectively (Fuentes et al., 2000). Furthermore, it has been suggested that the atmospheric oxidation of isoprene, in particular, can buffer the oxidative capacity of forested regions by maintaining levels of the hydroxyl radical $(\mathrm{OH})$ under lower nitric oxide $(\mathrm{NO})$ conditions (Lelieveld et al., 2008). Due to their large abundances, 
isoprene and monoterpenes also dominate the global budget of secondary organic aerosol (SOA) (Henze et al., 2008). Thus, the accurate representation of detailed chemistry for isoprene and monoterpene is necessary for meaningful simulations of atmospheric $\mathrm{HO}_{\mathrm{x}}\left(\mathrm{OH}+\mathrm{HO}_{2}\right), \mathrm{NO}_{\mathrm{x}}\left(\mathrm{NO}+\mathrm{NO}_{2}\right)$, surface ozone $\left(\mathrm{O}_{3}\right)$, trace gas lifetimes, and SOA.

Unsaturated hydrocarbons like isoprene and monoterpenes are primarily oxidized by $\mathrm{OH}, \mathrm{O}_{3}$, and the nitrate $\left(\mathrm{NO}_{3}\right)$ radical in the atmosphere. $\mathrm{OH}$ oxidation is the dominant fate for isoprene, but $\mathrm{O}_{3}$ and $\mathrm{NO}_{3}$ oxidation can dominate reactivity for monoterpenes and sesquiterpenes. Our understanding of the $\mathrm{OH}$-initiated isoprene oxidation mechanism has significantly improved during the last decade, following the first suggestion of the capacity of isoprene to produce SOA (Claeys et al., 2004). The mechanistic developments have been propelled by technological advancements in instrumentation (Hansel et al., 1995; Crounse et al., 2006; Jordan et al., 2009; Junninen et al., 2010), enabling the detection of more complex oxidation products derived from isoprene and other biogenic hydrocarbons. However, the scientific understanding of these biogenic oxidation mechanisms is far from complete. It is outside the scope of this overview to describe comprehensively the isoprene and monoterpene oxidation mechanisms. Rather, we provide a brief background of the oxidation of biogenic hydrocarbons, which includes "state-of-thescience" knowledge, to motivate the study. The mechanisms described here are illustrated in Scheme 1.

\subsubsection{OH oxidation}

OH predominantly adds to either of the double bonds of isoprene, followed by the reversible addition of $\mathrm{O}_{2}$ (Peeters et al., 2009) to produce several isomers of alkylperoxyl radicals $\left(\mathrm{RO}_{2}\right)$. In the atmosphere, these $\mathrm{RO}_{2}$ react mainly with $\mathrm{HO}_{2}$ and NO to form stable products, although self-reaction can be non-negligible under certain conditions. The stable products are often termed oxidized volatile organic compounds (OVOCs). In urban-influenced areas, the "high-NO" pathway is more important and in more pristine environments, the "low-NO" or $\mathrm{HO}_{2}$-dominated pathway is more important. The high-NO pathway generates isoprene hydroxy nitrates (ISOPN) that act as reservoirs for $\mathrm{NO}_{\mathrm{x}}$, as well as other products such as methyl vinyl ketone (MVK), methacrolein (MAC), and hydroxyacetone (HAC) (Paulot et al., 2009a). For conditions with sufficiently high $\mathrm{NO}_{2}$-to-NO ratios, as is mainly the case in the atmospheric boundary layer outside of cities, methacryloyl peroxynitrate (MPAN) is formed from the photooxidation of MAC. Further oxidation of MPAN can generate SOA (Chan et al., 2010, Surratt et al., 2010). The low-NO pathway generates isoprene hydroxy hydroperoxides (ISOPOOH) in almost quantitative yields, and further $\mathrm{OH}$ oxidation of ISOPOOH produces the epoxydiols in an OH-conserving mechanism (Paulot et al., 2009b). In unpolluted atmospheres, when the $\mathrm{RO}_{2}$ lifetimes are sufficiently long $\left(\sim 100 \mathrm{~s}\right.$ in a forest), isomerization of the $\mathrm{RO}_{2}$ followed by reaction with $\mathrm{O}_{2}$ becomes an important fate, producing the isoprene hydroperoxy aldehydes (HPALDs) and other products (Peeters et al., 2009; Crounse et al., 2011). These $\mathrm{RO}_{2}$ isomerization reactions are a type of rapid oxygen incorporation chemistry (Vereecken et al., 2007; Crounse et al., 2013; Ehn et al., 2014) that is thought to be responsible for the prompt generation of low-volatility SOA components. Further generations of $\mathrm{OH}$ oxidation in isoprene are currently being explored owing to recent success with chemical syntheses of important OVOCs (Wolfe et al., 2012; Jacobs et al., 2013; Bates et al., 2014; L. Lee et al., 2014). It has been found that the OH oxidation of IEPOX and ISOPN, surprisingly under both low-NO and high-NO conditions, results primarily in fragmentation of the $\mathrm{C}_{5}$ skeleton.

Despite extensive work on the isoprene $+\mathrm{OH}$ mechanism, large uncertainties persist, some of which directly translate into uncertainties in atmospheric model predictions. These uncertainties stem from, for example, the large range in reported yields for isoprene nitrates (4-15\%) (Paulot et al., 2009a), disagreements up to $90 \%$ in reported MAC and MVK yields from the low-NO pathway (Liu et al., 2013, and references therein), various proposed sources of SOA from the high-NO pathway (Chan et al., 2010; Kjaergaard et al., 2012; Lin et al., 2013), missing contributions to SOA mass from the low-NO pathway (Surratt et al., 2010), uncharacterized fates of oxidized species like HPALDs (which may have isomer dependence), incomplete understanding of oxygen incorporation (Peeters et al., 2009; Crounse et al., 2013), and under-characterized impact of $\mathrm{RO}_{2}$ lifetimes on chamber results (Wolfe et al., 2012). The $\mathrm{OH}$ oxidation of $\alpha$-pinene (Eddingsaas et al., 2012) and other monoterpenes is less well characterized than that of isoprene, but, in general, proceeds through analogous steps.

\subsubsection{Ozone oxidation}

Ozonolysis is a significant sink for unsaturated hydrocarbons and a large nighttime source of $\mathrm{OH}$, particularly in urbaninfluenced areas. Reaction with ozone is more important for monoterpenes than isoprene, due to the faster rate coefficients (Atkinson and Carter, 1984) and the nighttime emission profile for the monoterpenes. Furthermore, monoterpene ozonolysis is highly efficient at converting VOC mass to SOA (Hoffmann et al., 1997; Griffin et al., 1999). There is a general consensus that ozonolysis occurs via the Criegee mechanism (Criegee, 1975), wherein ozone adds to a hydrocarbon double bond to form a five-member primary ozonide that quickly decomposes to a stable carbonyl product and an energy-rich Criegee intermediate (CI). In $\alpha$-pinene oxidation, ozonolysis, $\mathrm{NO}_{3}$-initiated, and $\mathrm{OH}$-initiated reactions all produce pinonaldehyde $\left(\mathrm{C}_{10} \mathrm{H}_{16} \mathrm{O}_{2}\right)$ as a major product (Wängberg et al., 1997; Atkinson and Arey, 2003), whereas major first-generation products from isoprene ozonolysis include MAC, MVK, and formaldehyde. The "hot" Criegee can promptly lose $\mathrm{OH}$ (Kroll et al., 2001) while ejecting an 


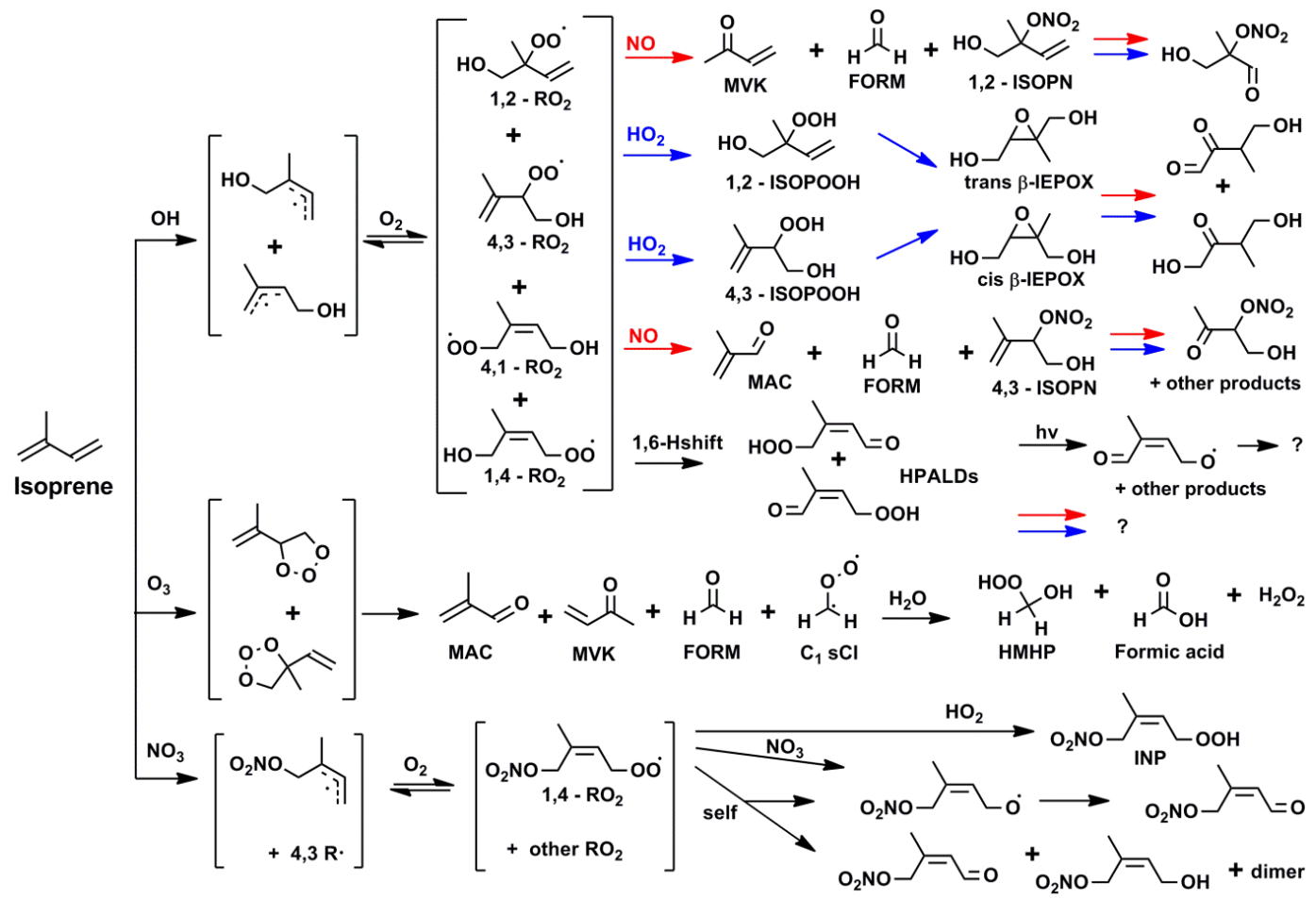

Scheme 1. Representative mechanism from the $\mathrm{OH}-, \mathrm{O}_{3}$ - and $\mathrm{NO}_{3}$-initated oxidation of isoprene. The most abundant isomers of a particular pathway are shown. Red and blue arrows in the OH-oxidation scheme denote the NO-dominated and $\mathrm{HO}_{2}$-dominated $\mathrm{RO}_{2}$ reactions, respectively. For the ozonolysis reaction, only the $\mathrm{C}_{1} \mathrm{sCI}$ and its reaction with water are shown as further-generation chemistry. For the $\mathrm{NO}_{3}$-oxidation pathway, only one isomer each of $\mathrm{R}$ and $\mathrm{RO}_{2}$ radicals is shown for brevity. Abbreviations are defined in the text.

alkyl radical, or become stabilized by collision with atmospheric gases to form a stabilized Criegee intermediate (sCI) with long enough lifetimes to react bimolecularly. The subsequent reactions of sCIs produce both carbonyl products and non-carbonyl products such as hydroperoxides. The syn and anti conformers of CIs and SCI can have substantially different reactivities (Kuwata et al., 2010; Anglada et al., 2011), with syn conformers more likely to decompose unimolecularly, possibly through a vinyl hydroperoxide intermediate (Donahue et al., 2011).

It has been suggested that reaction with water molecules is a major (if not dominant) bimolecular fate of sCI in the atmosphere due to the overwhelming abundance of atmospheric water (Fenske et al., 2000). This suggestion is supported by observations of high mixing ratios (up to $5 \mathrm{ppbv}$ ) of hydroxymethyl hydroperoxide (HMHP), a characteristic product of reactions of the smallest $\mathrm{sCI}\left(\mathrm{CH}_{2} \mathrm{OO}\right)$ with water (Neeb et al., 1997), over forested regions and in biomass burning plumes (Gäb et al., 1985; Lee et al., 1993, 2000; Valverde-Canossa et al., 2006). Although HMHP and other hydroperoxides produced from ozonolysis are important atmospheric compounds, their yield estimates are highly uncertain (Becker et al., 1990; Neeb et al., 1997; Sauer et al., 1999; Hasson et al., 2001; Huang et al., 2013). This may be attributable to the fact that hydroperoxide yields have mainly been determined by offline methods or under conditions with highly elevated hydrocarbon loadings. Furthermore, few empirical data exist on the humidity dependence of product branching in this reaction. Lastly, the rate coefficients for the $\mathrm{sCI}+\mathrm{H}_{2} \mathrm{O}$ reaction, and other sCI reactions, are still uncertain by several orders of magnitude (Johnson and Marston, 2008; Welz et al., 2012), precluding the assessment of their atmospheric importance.

\subsubsection{Nitrate oxidation}

$\mathrm{NO}_{3}$ oxidation also produces $\mathrm{RO}_{2}$ radicals by addition to alkenes in the presence of $\mathrm{O}_{2}$. Owing to its high reaction rate coefficient coupled to atmospheric abundance, $\alpha$-pinene is expected to be an important sink for $\mathrm{NO}_{3}$ in many areas. The $\mathrm{NO}_{3}$-derived $\mathrm{RO}_{2}$ radicals react with (a) $\mathrm{NO}_{3}$ to form alkoxy radicals (RO) that lead primarily to the production of nitrooxy carbonyls (b); with other $\mathrm{RO}_{2}$ radicals to form RO radicals, nitrooxy carbonyls, hydroxy nitrates, and nitrooxy peroxy dimers; and (c) with $\mathrm{HO}_{2}$ to form nitrooxy hydroperoxides. Further generation $\mathrm{NO}_{3}$-oxidation produces dinitrates, amongst other products. As the $\mathrm{NO}_{3}$ addition initiates the reaction, the thermodynamically preferred organic hydroxy nitrates produced through nighttime oxidation may be structurally different than those produced in the daytime through $\mathrm{OH}$ oxidation. During nighttime oxidation, tropo- 
spheric $\mathrm{HO}_{2}$ mixing ratios often surpass those of $\mathrm{NO}_{3}$ (Mao et al., 2012), implying $\mathrm{HO}_{2}$ reaction to be a common fate for $\mathrm{NO}_{3}$-derived $\mathrm{RO}_{2}$. However, previous studies of this reaction have maintained conditions where minimal $\mathrm{HO}_{2}+\mathrm{RO}_{2}$ chemistry occurs and the dominant fate of $\mathrm{RO}_{2}$ is reaction with $\mathrm{NO}_{3}$ and $\mathrm{RO}_{2}$ ( $\mathrm{Ng}$ et al., 2008; Perring et al., 2009; Rollins et al., 2009; Kwan et al., 2012). This may be one of the reasons why nitrooxy hydroperoxides (the $\mathrm{RO}_{2}+\mathrm{HO}_{2}$ product) are observed with much higher relative abundances in ambient air (Beaver et al., 2012) than in chamber studies.

\subsection{Scientific goals}

The 2014 Focused Isoprene eXperiment at the California Institute of Technology (FIXCIT) is a collaborative atmospheric chamber campaign focused on advancing the understanding of biogenic hydrocarbon oxidation in the atmosphere. The campaign was motivated by the communal need for a tight coupling of field and laboratory efforts toward understanding the mechanistic details responsible for ambient observations, exploring explicit chemistry as driven by the fate of $\mathrm{RO}_{2}$ radicals through well-controlled experiments, and fully characterizing instrumental response to important trace gases using authentic standards to guide data interpretation. To accomplish these goals, a suite of instruments typically deployed for field missions was used to perform parallel measurements at a forested site in Alabama and then in the atmospheric chambers at Caltech. This overview provides an account of the goals and conditions for the experiments performed during the campaign. A key component of FIXCIT is the re-design of "typical chamber experiments" to recreate the ambient atmosphere with higher fidelity so that results from laboratory studies can be implemented in models and used to interpret ambient observations with higher confidence.

\subsubsection{Understanding ambient observations}

FIXCIT was designed as a sister investigation to the 2013 Southern Oxidant and Aerosol Study (SOAS). During SOAS (June-July 2013), a select sub-suite of instruments recorded ambient observations above the forest canopy on top of a metal walk-up tower $20 \mathrm{~m}$ in height. The sampling site, located in Brent, Alabama at the Centreville (CTR) SEARCH location managed by the Electric Power Research Institute (CTR, latitude 32.90289 longitude -87.24968), was surrounded by a temperate mixed forest (part of the Talladega National Forest) that was occasionally impacted by anthropogenic emission. CTR was characterized by high atmospheric water content (2.4-3 vol. \% typically), elevated temperatures $\left(28-30^{\circ} \mathrm{C}\right.$ during the day), high SOA loadings (particulate organics $\sim 4-10 \mu \mathrm{g} \mathrm{m}^{-3}$; sulfate $\sim 2 \mu \mathrm{g} \mathrm{m}^{-3}$ ), high isoprene mixing ratios (4-10 ppbv), high ozone (4060 ppbv), low-to-moderate nitrogen oxides ([NO] $\sim 0.3-$ $\left.1.5 \mathrm{ppbv},\left[\mathrm{NO}_{2}\right] \sim 1-5 \mathrm{ppbv}\right)$, occasional plumes of $\mathrm{SO}_{2}$ from nearby power plants, and occasional biomass burning events during the SOAS campaign.

The first goal of the chamber campaign was to further investigate the more interesting observations at SOAS. Due to the ability of laboratory experiments to study the chemistry of a single reactive hydrocarbon in a controlled setting, it was possible to test hypotheses during FIXCIT in a systematic manner. Below we list some relevant questions from the SOAS campaign that were explored during FIXCIT.

1. Which reactions or environmental conditions control the formation and destruction of OVOCs in the southeastern US?

2. Are $\mathrm{RO}_{2}$ isomerization and other rapid oxygen incorporation mechanisms of key hydrocarbons important during SOAS?

3. How do anthropogenic influences, e.g., $\mathrm{NO}_{\mathrm{x}}, \mathrm{O}_{3}$, and $\left(\mathrm{NH}_{4}\right)_{2} \mathrm{SO}_{4}$, impact atmospheric chemistry over the forest?

4. How much does the $\mathrm{NO}_{3}$-initated reaction control nighttime chemistry during SOAS?

5. How do environmental conditions in the southeastern US affect ozonolysis end products, which are known to be water sensitive?

6. Which reactions or environmental conditions most significantly impact SOA mass and composition?

\subsubsection{Updating the isoprene and monoterpene mechanisms}

Several experiments were designed to "fill in the gaps" of the isoprene oxidation mechanisms by leveraging the comprehensive collection of sophisticated instrumentation at FIXCIT. We targeted the following acknowledged open questions.

7. What are the products of the photochemical reactions stemming from OVOCs like ISOPOOH, IEPOX, ISOPN, and pinonaldehyde?

8. What is the impact of photolysis vs. photooxidation for photolabile compounds?

9. What is the true yield of isoprene nitrates from the highNO photooxidation pathway?

10 What is the product distribution and true yield of nitrooxy hydroperoxides from the $\mathrm{NO}_{3}$ oxidation reaction of isoprene and monoterpenes under typical atmospheric conditions?

11. How do products and yields change as $\mathrm{RO}_{2}$ lifetimes in chamber studies approach values estimated to be prevalent in the troposphere? 


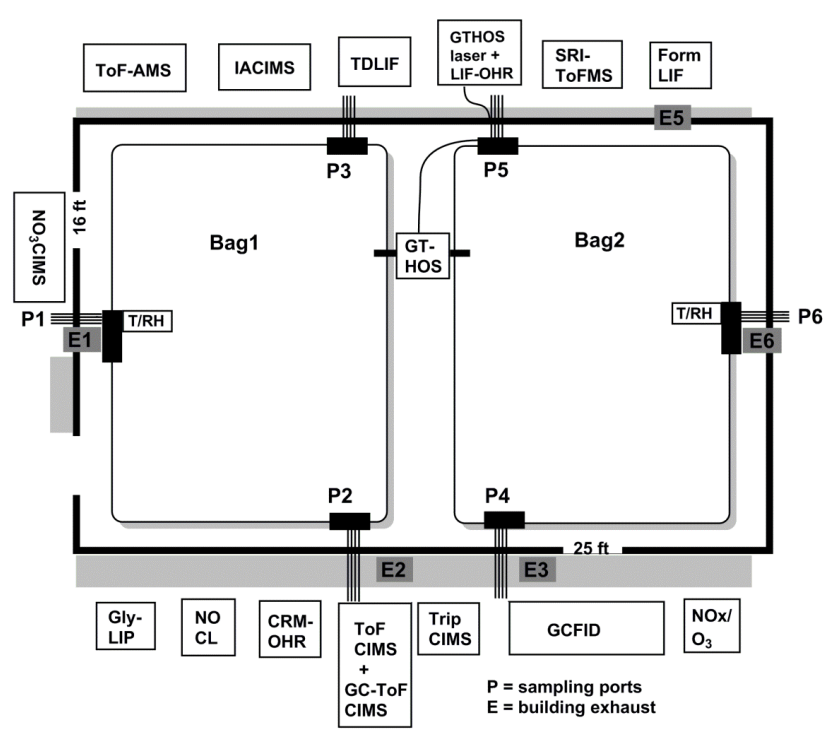

Figure 2. Arrangement of instruments at the Caltech Atmospheric Chamber Facility during the campaign. Instrument IDs are in Table 1.

\subsubsection{Instrument characterization}

A final goal of FIXCIT was to evaluate, compare, and identify biases in field instrumentation by isolating one variable at a time. We focused on the following objectives.

12. Identify the causal factor(s) producing the "OH interference" (Mao et al., 2012) that has been observed in various biogenically impacted regions by some gasexpansion laser-induced fluorescence (LIF) techniques.

13. Characterize the performance of newly commercially available CIMS instrumentation with respect to the detection of OVOCs by using authentic standards.

14. Compare similar measurements (e.g., OH reactivity, hydrocarbons, OVOCs) made with different techniques.

\section{Scope of the campaign}

\subsection{Facilities}

Experiments were performed in the Caltech Atmospheric Chamber Facility within a 1 month period in January 2014. The facility contains several in-house gas- and aerosol-phase instruments and an $8 \times 5 \mathrm{~m}$ insulated enclosure, housing two side-by-side Teflon atmospheric chambers that are suspended from the ceiling. The chambers were manufactured from fluorinated ethylene propylene (FEP) Teflon. The chamber volume was measured regularly by quantitative transfer of highly volatile organics such as isoprene by an externally calibrated GC-FID. Quantitative transfer was checked via injections of a measured quantity of isoprene (checked by gravimetric, volumetric, and FT-IR methods) into a pillow bag with known volume by timing a calibrated mass flow of air into the pillow bag. For most experiments, the chamber volume was between 23 and $24 \mathrm{~m}^{3}$. The spatial configuration of instruments in the chamber facility during FIXCIT is shown in Fig. 1. The instruments, contributors, and identifying abbreviations used in this work are described in Table 1. A total of $320 \mathrm{UV}$ black lamps (broadband $\lambda_{\max } \sim 350 \mathrm{~nm}$ ) are mounted on the walls of the enclosure. The lamps are located behind Teflon films so that the heat produced from the operation of the lamps can be removed by recirculating cool air. The interior of the enclosure is covered with reflective aluminum sheets. Light intensities can be tuned to 100 , 50,10 , and $1 \% . J_{\mathrm{NO}_{2}}$ was measured to be $7 \times 10^{-3} \mathrm{~s}^{-1}$ at $100 \%$ light intensity. Light fluxes at several locations within the chamber (e.g., center, corner, right, left, high, low) did not vary more than $15 \%$. Temperature controls in the chamber enclosure are tunable from 10 to $50^{\circ} \mathrm{C}$ (typically set at $25^{\circ} \mathrm{C}$ ) and did not fluctuate more than $1{ }^{\circ} \mathrm{C}$, except during periods when the temperature was explicitly changed or during a $30 \mathrm{~min}$ period immediately following a change in the light intensities (up to $2{ }^{\circ} \mathrm{C}$ increase was observed from switching on $100 \%$ lights.)

The chamber experiments were operated in batch mode throughout the campaign. Temperature and $\mathrm{RH}$ were monitored continuously inside the chamber by a Vaisala HMM211 probe calibrated with saturated salt solutions in the RH range of $11-95 \%$. In the range $\mathrm{RH}<11 \%$, water vapor measurements were provided by the TripCIMS. The chambers were flushed at least $24 \mathrm{~h}$ before each use with ultra-purified air (purified in-house via a series of molecular sieves, activated carbon, Purafil ${ }^{\mathrm{TM}}$ media, and particulate filters), at elevated temperature when needed $\left(\sim 40^{\circ} \mathrm{C}\right)$, so that the backgrounds on gas- and particle-phase instrumentation are at baseline levels. As a reference, NO levels before each run were typically less than 100 pptv (from NO-CL measurements) and particle concentrations were less than $0.01 \mu \mathrm{g} \mathrm{m}^{-3}$. Flushing rates, as balanced by exhaust rates, were typically $250 \mathrm{SD} \mathrm{L} \mathrm{min}^{-1}$ (SLM) or $\sim 0.6$ chamber volumes per hour. Chambers were mixed on the timescale of minutes by injecting high-pressure pulses of air during the beginning of experiments.

Chamber 1 was reserved for low-NO experiments, so that the walls did not contact elevated levels of nitric acid and organic nitrates during the lifetime of the chamber, while Chamber 2 was reserved for moderate- to high-NO experiments. Experiments were carried out daily in alternating chambers to allow for the full flushing period of the previously used chamber. Each chamber was characterized separately prior to the campaign for vapor and particle wall loss rates. Typically, wall loss rates for gas-phase species are slightly higher in the high-NO chamber than the low-NO chamber due to the greater acidity of the walls. Particle wall loss rates were not significantly different between chambers. 
Table 1. List of participating instruments, principle investigators (PIs), and institutions. Key acronyms: laser-induced fluorescence (LIF), laser-induced phosphorescence (LIP), high-resolution time-of-flight (HRToF), compact time-of-flight (CToF), MS (mass spectrometer), and CIMS (chemical ionization mass spectrometer).

\begin{tabular}{|c|c|c|c|c|c|}
\hline Instrument & Instr. ID & $\mathrm{PI}(\mathrm{s})$ & Institutions & Measurements & Ref. \\
\hline $\begin{array}{l}\text { Ground-based hydrogen } \\
\text { oxide sensor }\end{array}$ & GTHOS & W. H. Brune & $\begin{array}{l}\text { Pennsylvania State } \\
\text { University (PSU) }\end{array}$ & $\mathrm{OH}, \mathrm{HO}_{2}, \mathrm{RO}_{2}$ & Brune et al. (1995) \\
\hline LIF OH reactivity monitor & LIF-OHR & W. H. Brune & PSU & $\mathrm{OH}$ reactivity by decay of $\mathrm{OH}$ & Mao et al. (2009) \\
\hline $\begin{array}{l}\text { Thermal dissociation LIF } \\
\mathrm{NO}_{2} \text { monitor }\end{array}$ & TDLIF & R. C. Cohen & $\begin{array}{l}\text { University of Califor- } \\
\text { nia, Berkeley (UCB) }\end{array}$ & $\begin{array}{l}\mathrm{NO}_{2} \text {, sum of organic nitrates } \\
(\Sigma \mathrm{ANs}) \text {, sum of peroxy ni- } \\
\text { trates ( } \Sigma \mathrm{PNs}) \text {, particulate org. } \\
\text { nitrates ( } p \mathrm{ANs})\end{array}$ & Day et al. (2002) \\
\hline $\begin{array}{l}\text { Switchable iodide and ac- } \\
\text { etate ion HRToF-CIMS }\end{array}$ & IACIMS & D. K. Farmer & $\begin{array}{l}\text { Colorado State Univer- } \\
\text { sity (CSU) }\end{array}$ & $\begin{array}{l}\text { Oxidized VOCs (organic ni- } \\
\text { trates, organic acids, etc.) }\end{array}$ & Lee et al. (2014a) \\
\hline $\mathrm{NO}_{3}^{-}$HRToF- CIMS & $\mathrm{NO}_{3} \mathrm{CIMS}$ & $\begin{array}{l}\text { M. R. Canagaratna, } \\
\text { D. R. Worsnop, J. L. Jimenez }\end{array}$ & $\begin{array}{l}\text { Aerodyne Research, } \\
\text { Inc. (ARI) and Univ. } \\
\text { of Colorado, Boulder } \\
\text { (CUB) }\end{array}$ & $\begin{array}{l}\text { Low-volatility organic com- } \\
\text { pounds }\end{array}$ & Junninen et al. (2010) \\
\hline LIP glyoxal monitor & GlyLIP & F. N. Keutsch & $\begin{array}{l}\text { University of Wiscon- } \\
\text { sin, Madison (UWM) }\end{array}$ & Glyoxal & Huisman et al. (2008) \\
\hline $\begin{array}{l}\text { LIF formaldehyde moni- } \\
\text { tor }\end{array}$ & FormLIF & F. N. Keutsch & UWM & Formaldehyde & $\begin{array}{l}\text { Hottle et al. (2008); } \\
\text { DiGangi et al. (2011) }\end{array}$ \\
\hline $\begin{array}{l}\text { Comparative rate method } \\
\text { OH reactivity monitor }\end{array}$ & CRM-OHR & S. Kim, A. B. Guenther & $\begin{array}{l}\text { Univ. of California, } \\
\text { Irvine (UCI) and Pa- } \\
\text { cific NW National Lab } \\
\text { (PNNL) }\end{array}$ & $\begin{array}{l}\text { OH reactivity by decay of hy- } \\
\text { drocarbons }\end{array}$ & Sinha et al. (2008) \\
\hline $\begin{array}{l}\text { Switchable reagent ion } \\
\left(\mathrm{H}_{3} \mathrm{O}^{+} / \mathrm{NO}^{+} / \mathrm{O}_{2}^{+}\right) \\
\text {HRToF -MS }\end{array}$ & SRI-ToFMS & $\begin{array}{l}\text { A. B. Guenther, J. E. Mak, } \\
\text { A. H. Goldstein }\end{array}$ & $\begin{array}{ll}\text { PNNL, SUNY Stony- } \\
\text { brook } \\
\text { UCB }\end{array}$ & $\begin{array}{l}\text { Hydrocarbons, carbonyls, al- } \\
\text { cohols, etc. }\end{array}$ & Jordan et al., 2009 \\
\hline $\begin{array}{l}\text { Chemical luminescence } \\
\text { NO monitor }\end{array}$ & $\mathrm{NO}-\mathrm{CL}$ & $\begin{array}{l}\text { G. S. Tyndall, D. D. Montzka, } \\
\text { A. J. Weinheimer }\end{array}$ & $\begin{array}{l}\text { National Center for } \\
\text { Atmospheric Research } \\
\text { (NCAR) }\end{array}$ & $\mathrm{NO}(>25 \mathrm{pptv})$ & $\begin{array}{l}\text { Ridley and } \\
\text { Grahek (1990) }\end{array}$ \\
\hline $\begin{array}{l}\mathrm{CF}_{3} \mathrm{O}^{-} \text {triple quadrupole } \\
\text { CIMS }\end{array}$ & TripCIMS & P. O. Wennberg & $\begin{array}{l}\text { California Institute of } \\
\text { Technology (Caltech) }\end{array}$ & $\begin{array}{l}\text { ISOPOOH, IEPOX, glyco- } \\
\text { laldehyde, acetic acid, methyl } \\
\text { hydroperoxide }\end{array}$ & St. Clair et al. (2010) \\
\hline $\mathrm{CF}_{3} \mathrm{O}^{-}$CToF-CIMS & ToFCIMS & P. O. Wennberg & Caltech & $\begin{array}{l}\text { Oxygenated VOCs (hydroper- } \\
\text { oxides, organic nitrates, multi- } \\
\text { functional compounds) }\end{array}$ & Crounse et al. (2006) \\
\hline $\begin{array}{l}\text { Gas chromatograph with } \\
\text { ToFCIMS }\end{array}$ & GC-ToFCIMS & P. O. Wennberg & Caltech & Isomers for oxygenated VOCs & Bates et al. (2014) \\
\hline $\begin{array}{l}\text { HRToF-aerosol mass } \\
\text { spectrometer }\end{array}$ & ToF-AMS & J. H. Seinfeld & Caltech & $\begin{array}{l}\text { Aerosol composition and size } \\
\text { distribution }\end{array}$ & $\begin{array}{l}\text { DeCarlo et al. (2006); } \\
\text { Canagaratna et al. (2007) }\end{array}$ \\
\hline $\begin{array}{l}\text { Gas chromatograph with } \\
\text { flame-ionization detector }\end{array}$ & GCFID & J. H. Seinfeld & Caltech & $\begin{array}{l}\text { Isoprene, methacrolein, } \\
\text { methyl vinyl ketone, cyclo- } \\
\text { hexane }\end{array}$ & N/A \\
\hline $\begin{array}{l}\text { Thermocouple and } \\
\text { membrane probe }\end{array}$ & $T$ / RH probe & J. H. Seinfeld & Caltech & $\begin{array}{l}\text { Temperature and relative hu- } \\
\text { midity }\end{array}$ & N/A \\
\hline $\begin{array}{l}\text { UV-absorption ozone } \\
\text { monitor }\end{array}$ & $\mathrm{O}_{3}$ monitor & J. H. Seinfeld & Caltech & $\mathrm{O}_{3}(>1000 \mathrm{pptv})$ & N/A \\
\hline $\begin{array}{l}\text { Chemical luminescence } \\
\mathrm{NO}_{\mathrm{x}} \text { detector }\end{array}$ & $\mathrm{NO}_{\mathrm{x}}$ monitor & J. H. Seinfeld & Caltech & $\begin{array}{l}\mathrm{NO}\left(>500 \text { pptv), and } \mathrm{NO}_{2}\right. \\
\text { (catalytic conversion to } \mathrm{NO} \text { ) }\end{array}$ & N/A \\
\hline
\end{tabular}

Measurements of the particle wall loss rates were performed by injecting ammonium sulfate (AS) seed aerosols into the chamber and monitoring the decay over the course of 10$24 \mathrm{~h}$. Particles were injected via atomization of dilute salt solutions (e.g., AS $0.06 \mathrm{M}$ ) through a ${ }^{210}$ Po neutralizer and water trap. Measurements of vapor wall loss rates were per- formed by injecting OVOC standards (e.g., IEPOX, HMHP, etc.) into the chamber. Both particle and vapor wall loss characterizations were performed at several $\mathrm{RH}$ conditions (4-85\% RH). These characterizations have been described in more detail previously (Loza et al., 2010; Nguyen et al., 2014). 
Organic compounds were injected into the chamber by two methods. (1) For volatile compounds, a measured volume was injected with a micro-syringe through a septum into a clean glass bulb, and the evaporated standard was quantitatively transferred into the chamber by dry purified air. Gas introduction of VOCs (done for isoprene and methacrolein) by filling an evacuated bulb with the chemical vapor, backfilling with nitrogen gas, and characterizing with Fourier transform infrared spectrometry before injecting did not produce significantly different results than volume injection. (2) For semivolatile compounds, the solid or liquid standard was placed inside a two-neck flask, which was heated by a water bath $\left(35-65^{\circ} \mathrm{C}\right)$, and the headspace was carried into the chamber by dry purified air. The ToFCIMS or TripCIMS instruments measured the gas-phase mixing ratio of the semi-volatiles in real time as the compounds entered the chamber, and injection was halted when a satisfactory quantity was introduced. OVOCs were calibrated by the ToFCIMS and TripCIMS by methods described earlier (Paulot et al., 2009a). The desired RH inside the chamber was achieved by flowing dry purified air through a water-permeable (Nafion) membrane humidifier (FC200, Permapure LLC), kept moist by recirculating $27^{\circ} \mathrm{C}$ ultra-purified (18 M $\Omega, 3 \mathrm{ppb}$ TOC) water (Milli-Q, Millipore Corp). Particles were atomized into the chamber as described for particle wall loss experiments. When hydrated particles were needed for experiments, particles were injected via an in-line, heated, wet-wall denuder into a chamber that has RH above the efflorescence point of the particular salt (Martin, 2000).

\subsection{Instrumentation and sampling modifications}

Instruments were connected via sampling lines to both chambers through port holes in the enclosure as shown in Fig. 1. Sampling lines were capped when not in use. Inlet and tubing material were instrument specific, and included stainless steel (GTHOS and ToF-AMS), heated stainless steel and quartz (TDLIF), electro-polished steel and FEP Teflon ( $\mathrm{NO}_{3} \mathrm{CIMS}$ ), polyetheretherketone (PEEK) and Teflon (SRIToFMS), and perfluoroalkoxy polymer (PFA) Teflon (other instruments).

The duration of each experiment (i.e., the level of oxidation that can be probed) was critically dependent on the net sampling flow rates at which air was withdrawn from the chamber. Sampling strategies were developed to minimize the effective sampling flow rate from each instrument, in such a way that instrument responses were not significantly different than during field campaigns. In many cases, a common high-flow Teflon sampling line was used to minimize the residence time of gases through tubing, and smaller flows were sampled orthogonally by each instrument. In some cases, a duty cycle was used as needed.

Several modifications from field designs were utilized for chamber sampling. The modifications were that (1) the GTHOS detection system was located between the cham- bers inside of the enclosure to minimize the residence time of $\mathrm{HO}_{\mathrm{x}}$ inside the instrument (Fig. 1). The detection system was connected to the laser on the outside of the enclosure via a $3 \mathrm{~m}$ fiber optic cable fed through the side port hole. The sampling flow rate was similar to field flows (6 SLM); however, the fast-flow inlet was situated horizontally ( $\sim 2 \mathrm{~m}$ in height) instead of vertically. The inlet was adapted to each bag directly, by attaching it to a Teflon plate that was in turn secured to the chamber walls via a large o-ring. The GTHOS inlet switched from Chamber 1 to Chamber 2 as needed. Chemical zeroing was performed by releasing hexafluoropropene $\left(\mathrm{C}_{3} \mathrm{~F}_{6}\right)$ into the inlet as an $\mathrm{OH}$ scrubber, and dark zeroing by measuring the difference between online and offline signals. Chemical and dark zeroing methods were used to distinguish between $\mathrm{OH}$ present in the chamber or atmosphere (chemical $\mathrm{OH}$ ) and $\mathrm{OH}$ that may have been produced after the gas stream enters the instrument, which is additional to the chemical OH signal; (2) LIF-OHR was diluted a factor of 10 with nitrogen gas (effective flow $6 \mathrm{SLM}$ ); (3) $\mathrm{NO}_{3}$ CIMS was diluted a factor of 5 with scrubbed zero air (effective flow 2 SLM); (4) GlyLIP and FormLIF both operated at 5 SLM instead of the usual 17 and 10 SLM, respectively; and (5) SRIToFMS (1.5 SLM) and GCFID (0.1 SLM) occasionally sampled through a $0.125-0.25^{\prime \prime}$ OD PFA Teflon tube that was submerged in a cold bath kept at $-40^{\circ} \mathrm{C}$ in order to remove interferences from certain OVOC (see Sect. 2.3).

GC-ToFCIMS, first described in Bates et al. (2014), is an extension of the ToFCIMS. Analyte gas samples were focused with a cold trap onto the head of a RTX 1701 column (Restek) and eluted with a temperature ramping program $\left(30-130{ }^{\circ} \mathrm{C}\right)$ in the oven before reaching the ToFCIMS for mass spectrometry detection. GC-ToFCIMS recorded data only when isomer separation was needed, because its operation took the standard scanning mode of the ToFCIMS offline. All other instruments operated normally with the following sampling flows: TDLIF (4 SLM), ToFCIMS and TripCIMS (2 SLM), CRM-OHR (0.5 SLM), NO-CL (1 SLM), and IACIMS (2 SLM). Frequencies of zeroing (with dry $\mathrm{N}_{2}$ or ultrazero air) and calibration (various methods) were instrument specific, with some instruments zeroing once per hour and calibrating once every few hours and others performing zeroing/calibration between experiments.

\subsection{Experimental design}

The experiments performed at FIXCIT can be divided into several categories, each probing one or more specific science questions outlined in Sect. 1.2. Every experiment included successful elements from past studies, but with a special focus on extending to atmospheric conditions. One example is reducing the occurrence of $\mathrm{RO}_{2}+\mathrm{RO}_{2}$ side reactions in chamber experiments, which can lead to yields of atmospherically relevant products that are biased low. Enabled by the high sensitivity of field instruments, photooxidation was per- 
Table 2. Formal experiments and reaction conditions during the campaign. Chemical abbreviations are defined in Table 3. Other abbreviations are $\mathrm{C} 1=$ Chamber $1, \mathrm{C} 2=$ Chamber $2, \mathrm{ISOP}=$ isoprene, $\alpha$-PIN $=\alpha$-pinene, $\mathrm{HP}=$ hydrogen peroxide, $\mathrm{MN}=$ methyl nitrite, $\mathrm{CHX}=$ cyclohexane, $\mathrm{HCHO}=$ formaldehyde, $\mathrm{AS}=$ ammonium sulfate seeds. Exp. types are defined in the text. Exp. no. corresponds to the date in January 2014 when the experiment was performed.

\begin{tabular}{|c|c|c|c|c|c|c|c|c|c|c|c|c|c|}
\hline No. & $\begin{array}{l}\text { Exp. } \\
\text { type }\end{array}$ & $\begin{array}{l}\mathrm{HC} \\
\text { precursor }\end{array}$ & $\begin{array}{l}{[\mathrm{HC}]} \\
\text { (ppb) }\end{array}$ & $\mathrm{O}_{\mathrm{x}}$ & $\begin{array}{l}\mathrm{O}_{\mathrm{x}} \\
\text { source }\end{array}$ & $\begin{array}{l}{[\mathrm{OH}]_{\mathrm{ss}}} \\
\left(\# \mathrm{~cm}^{-3}\right)\end{array}$ & $\begin{array}{l}{\left[\mathrm{O}_{3}\right]_{i}} \\
(\mathrm{ppb})\end{array}$ & $\begin{array}{l}{[\mathrm{NO}]_{i}} \\
(\mathrm{ppb})\end{array}$ & $\begin{array}{l}{\left[\mathrm{NO}_{2}\right]_{i}} \\
(\mathrm{ppb})\end{array}$ & $\begin{array}{l}{[\mathrm{NO}] / /} \\
{\left[\mathrm{HO}_{2}\right]}\end{array}$ & $\begin{array}{l}\text { Add'l } \\
\text { inj. }\end{array}$ & $\begin{array}{l}\operatorname{Rxn} T \\
\left({ }^{\circ} \mathrm{C}\right)\end{array}$ & $\begin{array}{l}\mathrm{RH} \\
(\%)\end{array}$ \\
\hline 2 & $\mathrm{~b}$ & ISOP & 45 & $\mathrm{OH}$ & $\mathrm{HP}+h v$ & $1.5 \times 10^{6}$ & $<5$ & $<0.04$ & $<2$ & $1 / 7$ & - & 27 & $<5$ \\
\hline 3 & $\mathrm{c}$ & ISOP & 100 & $\mathrm{OH}$ & $\mathrm{HP}+h v$ & $2.4 \times 10^{6}$ & $<5$ & 500 & 15 & $>100$ & - & 26 & $<5$ \\
\hline $4 a$ & $\mathrm{i}$ & ISOPOOHs & 250 & - & - & - & - & - & - & - & - & 24 & $<3$ \\
\hline $4 \mathrm{~b}$ & a & Blank C1 & 0 & $\mathrm{OH}$ & $\mathrm{HP}+h v$ & $2.0 \times 10^{6}$ & $<5$ & $<0.04$ & $<3$ & $1 / 6$ & - & $27-33$ & $<5$ \\
\hline $5 \mathrm{a}$ & $\mathrm{i}$ & ISOPNs & $<13$ & - & - & - & - & - & - & - & - & 24 & $<3$ \\
\hline $5 b$ & $\mathrm{a}$ & Blank C2 & 0 & $\mathrm{OH}$ & $\mathrm{HP}+h v$ & $2.0 \times 10^{6}$ & $<5$ & $<0.04$ & $<2$ & $1 / 5$ & - & 27 & $<5$ \\
\hline 6 & $\mathrm{e}$ & ISOP & 91 & $\mathrm{O}_{3}$ & $\mathrm{O}_{3} \mathrm{rxn}$ & $\begin{array}{l}{[\mathrm{OH}]_{i}} \\
\sim \underset{1 \times 10^{6}}{ }\end{array}$ & 615 & $<0.04$ & $<3$ & - & - & 25 & $<5$ \\
\hline $7^{*}$ & d & ISOP & 30 & $\mathrm{OH}$ & $\mathrm{MN}+h v$ & $\begin{array}{l}4.1 \times 10^{4} \\
4.8 \times 10^{6}\end{array}$ & $<5$ & 0.08 & 45 & 2,6 & - & 40,40 & $<5$ \\
\hline 9 & $\mathrm{f}$ & ISOP & 18 & $\mathrm{NO}_{3}$ & $\mathrm{NO}_{2} / \mathrm{O}_{3}$ & $3.8 \times 10^{8}$ & 55 & 0.10 & 100 & $2-3$ & $\mathrm{HCHO}$ & 26 & $<5$ \\
\hline 10 & $\mathrm{~b}$ & $\alpha-\mathrm{PIN}$ & 30 & $\mathrm{OH}$ & $\mathrm{HP}+h v$ & $2.0 \times 10^{6}$ & $<5$ & $<0.04$ & $<2$ & $1 / 10$ & - & 27 & $<5$ \\
\hline 11 & c & $\alpha-\mathrm{PIN}$ & 30 & $\mathrm{OH}$ & $\mathrm{HP}+h v$ & $2.5 \times 10^{6}$ & $<5$ & 85 & 10 & $>100$ & - & 26 & $<5$ \\
\hline 13 & $\mathrm{f}$ & $\alpha-\mathrm{PIN}$ & 30 & $\mathrm{NO}_{3}$ & $\mathrm{NO}_{2} / \mathrm{O}_{3}$ & $4 \times 10^{8}$ & 75 & 0.17 & 150 & $1.5-8$ & $\mathrm{HCHO}$ & 25 & $<5$ \\
\hline 14 & $\mathrm{e}$ & ISOP & 100 & $\mathrm{O}_{3}$ & $\mathrm{O}_{3} \mathrm{rxn}$ & $\begin{array}{l}{[\mathrm{OH}]} \\
\sim 0\end{array}$ & 605 & $<0.04$ & $<3$ & - & CHX & 25 & $<5$ \\
\hline $16^{*}$ & d & $\alpha-\mathrm{PIN}$ & 30 & $\mathrm{OH}$ & $\mathrm{MN}+h v$ & $\begin{array}{l}6 \times 10^{4} \\
4 \times 10^{6}\end{array}$ & $<5$ & 0.08 & $<3$ & $\begin{array}{l}2-3, \\
10\end{array}$ & - & 40,40 & $<5$ \\
\hline 17 & $\mathrm{~b}, \mathrm{i}$ & 4,3- ISOPOOH & 60 & $\mathrm{OH}$ & $\mathrm{HP}+h v$ & $1.2 \times 10^{6}$ & $<5$ & $<0.04$ & $<3$ & $1 / 5$ & - & 26 & $<5$ \\
\hline $18^{*}$ & d & ISOP & 28 & $\mathrm{OH}$ & $\mathrm{MN}+h v$ & $\begin{array}{l}1.0 \times 10^{5} \\
4.3 \times 10^{6}\end{array}$ & $<5$ & 0.08 & $<3$ & $\begin{array}{l}2-3 \\
>100\end{array}$ & - & 25,26 & $<5$ \\
\hline 19 & $\mathrm{~b}, \mathrm{~h}$ & ISOP & 60 & $\mathrm{OH}$ & $\mathrm{HP}+h v$ & $1.0 \times 10^{6}$ & $<5$ & $<0.04$ & $<4$ & $1 / 5$ & wet AS & 28 & 51 \\
\hline 21 & $\mathrm{~b}$ & ISOP & 22 & $\mathrm{OH}$ & $\mathrm{HP}+h v$ & $2.0 \times 10^{6}$ & $<5$ & $<0.04$ & $<2$ & $1 / 10$ & - & 27 & $<5$ \\
\hline 22 & $\mathrm{c}$ & ISOP & 100 & $\mathrm{OH}$ & $\mathrm{HP}+h v$ & $2.3 \times 10^{6}$ & $<5$ & 430 & 15 & $>100$ & - & 27 & $<5$ \\
\hline 23 & $\mathrm{e}$ & ISOP & 90 & $\mathrm{O}_{3}$ & $\mathrm{O}_{3} \mathrm{rxn}$ & $\begin{array}{l}{[\mathrm{OH}]_{i}} \\
\sim \\
1 \times 10^{6}\end{array}$ & 600 & $<0.04$ & $<3$ & - & - & 25 & 50 \\
\hline 24 & $\mathrm{c}, \mathrm{h}, \mathrm{i}$ & 4,3-ISOPN & 12 & $\mathrm{OH}$ & $\mathrm{HP}+h v$ & $3 \times 10^{6}$ & 7 & 115 & 55 & $>100$ & wet AS & 26 & 52 \\
\hline 25 & $\mathrm{~b}$ & MAC & 43 & $\mathrm{OH}$ & $\mathrm{HP}+h v$ & $3 \times 10^{6}$ & $<5$ & $<0.03$ & $<3$ & $1 / 10$ & - & 28 & $<5$ \\
\hline 26 & $\mathrm{~g}, \mathrm{~h}$ & MAC & 45 & $\mathrm{OH}$ & $\mathrm{MN}+h v$ & $2 \times 10^{7}$ & $<5$ & 3.5 & 50 & $10-20$ & $\begin{array}{l}\text { MAE, } \\
\text { wet AS }\end{array}$ & 26 & $<5,40$ \\
\hline 27 & $\mathrm{~d}, \mathrm{i}$ & trans $\beta$-IEPOX & 60 & $\mathrm{OH}$ & $\mathrm{MN}+h v$ & $7.3 \times 10^{6}$ & $<5$ & 0.25 & $<3$ & $2-5$ & - & 25 & $<5$ \\
\hline 29 & e & ISOP & 91 & $\mathrm{O}_{3}$ & $\mathrm{O}_{3} \mathrm{rxn}$ & $\begin{array}{l}{[\mathrm{OH}]} \\
\sim 0\end{array}$ & 610 & $<0.04$ & $<4$ & - & CHX & 25 & 38 \\
\hline 30 & $\mathrm{~g}, \mathrm{~h}, \mathrm{i}$ & Pinonald. & 15 & $\mathrm{OH}$ & $\mathrm{MN}+h v$ & $3.5 \times 10^{6}$ & $<5$ & 0.50 & $<3$ & $4-8$ & - & 26 & $<5$ \\
\hline
\end{tabular}

$* 1 \%$ lights, $20 \%$ lights, then $100 \%$ lights.

formed with precursor mixing ratios as low as $12 \mathrm{ppbv}$. Certain instruments that required extensive dilution in a chamber setting, e.g., LIF-OHR, had poorer-quality data for lowloading experiments. Experimental durations were typically 4-6h, with the exception of overnight runs where the majority of instruments sampled briefly to establish starting con- ditions, then were taken offline during the nighttime and resumed sampling in the morning. The typical reaction time for an overnight experiment was $\sim 15 \mathrm{~h}$. Experimental details are reported in Table 2. $\mathrm{OH}$ concentrations were derived from hydrocarbon decay data from GCFID, SRI-ToFMS, or ToFCIMS, when available, using published rate coefficients 
(Atkinson et al., 2006; L. Lee et al., 2014; Bates et al., 2014). Otherwise, preliminary GTHOS chemical-zeroing data were used. The following types of experiments were included in the study:

a. Blank (Exp. 4b and 5b): blank experiments were designed to investigate background signals present in experiments that may have sources other than gas-phase chemistry of the injected hydrocarbon, e.g., from heterogeneous oxidation of residual organics on the chamber walls. $\mathrm{OH}$ precursors, such as hydrogen peroxide, were added to each chamber, the UV lamps were turned on, and sampling occurred as usual. Furthermore, the temperatures inside the chambers were ramped from 25 to $35^{\circ} \mathrm{C}$ to explore the extent to which elevated temperatures change the chamber background signals due to increased volatilization of organics. Blank experiments were performed under dry conditions. Common background compounds produced from heterogeneous wall reactions are formic acid and acetic acid.

b. Low-NO photooxidation (Exp. 2, 10, 17, 19, and 25): the low-NO experiments that have been extensively investigated in atmospheric chamber studies were designed to be relevant to the pristine troposphere, and certain conditions at SOAS, where $\mathrm{HO}_{2}$ reactions dominate the $\mathrm{RO}_{2}$ fate. Experiments were initiated by $\mathrm{H}_{2} \mathrm{O}_{2}$ photolysis as a $\mathrm{NO}_{\mathrm{x}}$-free source of $\mathrm{OH}$ and $\mathrm{HO}_{2}$ :

$$
\begin{aligned}
& \mathrm{H}_{2} \mathrm{O}_{2}+\mathrm{h} v \rightarrow \mathrm{OH}+\mathrm{OH} \\
& \mathrm{OH}+\mathrm{H}_{2} \mathrm{O}_{2} \rightarrow \mathrm{HO}_{2}+\mathrm{H}_{2} \mathrm{O} .
\end{aligned}
$$

The execution of these experiments requires precise engineering to simulate the troposphere closely. One outstanding challenge of low-NO experiments is the variation in initial NO levels across different chamber settings and on different days. Because typical $\mathrm{HO}_{2}$ levels in a chamber environment do not typically exceed $\sim 200$ pptv from the self-limiting $\mathrm{HO}_{2}$ recombination, NO should be $\sim 40$ pptv during the reaction (a factor of 5 less abundant) in order for the $\mathrm{C}_{5} \mathrm{RO}_{2}$ reactions to be dominated by $\mathrm{HO}_{2}$ by a factor of $10\left(k_{R O 2+H O 2} \sim 1.6 \times 10^{-11}\right.$ and $k_{R O 2+N O}$ $\sim 8.5 \times 10^{-12} \mathrm{~cm}^{3} \mathrm{molec}^{-1} \mathrm{~s}^{-1}$ at $298 \mathrm{~K}$ (Atkinson et al., 2006)). Thus, experimental variations in NO that can lead to discrepancies in low-NO kinetics typically elude quantification by commercially available NO chemiluminesence instruments, owing to their high limits of detection $(\sim 500 \mathrm{pptv})$.

NO levels in the Caltech chambers were suppressed by continually flushing with filtered air on the inside and outside the chamber walls. Initial NO levels of $<40 \mathrm{pptv}$ were typically achieved during experiments. The NO-CL instrument available during FIXCIT (Table 1) has a limit of detection better than $25 \mathrm{pptv}$, and the
GTHOS instrument provided online $\mathrm{HO}_{2}$ quantification at the pptv level. Another common challenge for low$\mathrm{NO}$ experiments (even when [NO] is less than $\left[\mathrm{HO}_{2}\right]$ ) is that homogeneous or cross $\mathrm{RO}_{2}+\mathrm{RO}_{2}$ reactions may dominate the $\mathrm{RO}_{2}$ reactivity $\left(k_{\mathrm{RO}_{2}+\mathrm{RO}_{2}} \sim 10^{-15}\right.$ $10^{-11} \mathrm{~cm}^{3} \mathrm{molec}^{-1} \mathrm{~s}^{-1}$ at $298 \mathrm{~K}$; Atkinson et al., 2006). These experiments may be more correctly characterized as "low-NO, high- $\mathrm{RO}_{2}$ ". For experiments using $\left[\mathrm{H}_{2} \mathrm{O}_{2}\right]$ as an $\mathrm{OH}$ precursor, $\mathrm{RO}_{2}+\mathrm{RO}_{2}$ reactions were largely minimized by using reaction conditions that ensure $\left[\mathrm{HO}_{2}\right]$ greater than $\left[\mathrm{RO}_{2}\right]$ (e.g., $\left[\mathrm{H}_{2} \mathrm{O}_{2}\right]_{0} /[\mathrm{ISOP}]_{0}$ $\sim 10^{2}$ and $\left.J\left[\mathrm{H}_{2} \mathrm{O}_{2}\right] \sim 4-5 \times 10^{-6} \mathrm{~s}^{-1}\right)$. Thus, the peroxy radical self-reaction channels are minor compared to $\mathrm{RO}_{2}+\mathrm{HO}_{2}$ chemistry. We estimate that the low-NO experiments were $\mathrm{HO}_{2}$-dominated by at least a factor of 10 in $\mathrm{RO}_{2}$ reactivity by monitoring tracers of chemistry stemming from high-NO (isoprene nitrates), high- $\mathrm{RO}_{2}\left(\mathrm{C}_{5}\right.$ diols and other products), and low-NO (ISOPOOH and IEPOX) pathways. The molar yield of the low-NO products ISOPOOH + IEPOX (measured within the first $15 \mathrm{~min}$ of reaction) was estimated at $95 \%$, supporting the dominance of $\mathrm{RO}_{2}+\mathrm{HO}_{2}$ chemistry over other channels. The structurally isomeric ISOPOOH and IEPOX that were formed from the $\mathrm{HO}_{2}$ dominated isoprene photooxidation were distinguished by TripCIMS, and the sum was measured by ToFCIMS, IACIMS, and $\mathrm{NO}_{3} \mathrm{CIMS}$. These experiments were performed with isoprene, $\alpha$-pinene, 4,3-ISOPOOH and MAC precursors.

c. High-NO photooxidation (Exp. 3, 11, 22, and 24): high-NO experiments are also commonly performed in chamber studies. These experiments were designed to be relevant to the urban-influenced troposphere, such as some cases at SOAS, where $\mathrm{NO}$ can dominate $\mathrm{RO}_{2}$ reactions. Experiments were typically initiated by $\mathrm{H}_{2} \mathrm{O}_{2}$ with added NO during FIXCIT, but have been performed using $\mathrm{HONO}$ or other precursors elsewhere. It is easier to ensure that reaction with $\mathrm{NO}$ is the main fate of $\mathrm{RO}_{2}$, even with higher hydrocarbon loadings, because $\mathrm{NO}$ mixing ratios are typically in excess of both $\mathrm{HO}_{2}$ and $\mathrm{RO}_{2}$ by hundreds of ppbv. Hydroxy nitrate products were measured by TDLIF, IACIMS, ToFCIMS, and GC-ToFCIMS. Functionalized carbonyl products were measured by SRI-ToFMS and ToFCIMS. Glyoxal and formaldehyde, also important high-NO products, were measured by the GlyLIP and FormLIF, respectively. This well-studied experiment was important for multiple reasons, including calibration, diagnostics, and for determining the hydroxy nitrate yields from alkenes within the first few minutes of photooxidation. However, it should be noted that the experimental result represents a boundary condition that may not fully represent NO-influenced reactions in the atmosphere due to the extremely short $\mathrm{RO}_{2}$ lifetimes $(<0.01 \mathrm{~s}$ at $500 \mathrm{ppbv}$ 
NO). These experiments were performed with isoprene, $\alpha$-pinene, and the 4,3-ISOPN standard synthesized by the Caltech group.

d. Slow chemistry photooxidation (Exp. 7, 16, 18, and 27): the slow chemistry experiment is designed to extend $\mathrm{RO}_{2}$ lifetimes closer to atmospheric values when both $\mathrm{NO}$ and $\mathrm{HO}_{2}$ impact $\mathrm{RO}_{2}$ reactivity $(\sim 3-30 \mathrm{~s}$, assuming 1500-100 pptv NO and 40 pptv $\mathrm{HO}_{2}$ ). This was achieved by employing low radical mixing ratios. With relevant $\mathrm{RO}_{2}$ lifetimes, the $\mathrm{RO}_{2}$ isomers may be closer to their equilibrium distribution because of the reversible addition of oxygen (Peeters et al., 2009). Figure 2 shows the progress of a representative slow chemistry experiment. The "slow" portion of experiments was performed under a low light flux $\left(\mathrm{N}_{\mathrm{NO}_{2}}\right.$ $\sim 4 \times 10^{-5} \mathrm{~s}^{-1}$ ) with methyl nitrite as the $\mathrm{OH}$ precursor (Atkinson et al., 1981):

$$
\begin{aligned}
& \mathrm{CH}_{3} \mathrm{ONO}+\mathrm{h} v+\mathrm{O}_{2} \rightarrow \mathrm{HO}_{2}+\mathrm{NO}+\mathrm{HCHO} \\
& \mathrm{HO}_{2}+\mathrm{NO} \rightarrow \mathrm{OH}+\mathrm{NO}_{2} .
\end{aligned}
$$

These reactions produce a steady-state $\mathrm{OH}$ concentration of $[\mathrm{OH}]_{\mathrm{ss}} \sim 0.4-1 \times 10^{5}$ molec cm $\mathrm{cm}^{-3}$ and an atmospherically relevant ratio of $\mathrm{NO} / \mathrm{HO}_{2}(2-3)$ that is stable throughout the majority of the experiment. Furthermore, we aimed to simulate the summer conditions at SOAS, where $\mathrm{RO}_{2}$ isomerization is competitive with $\mathrm{RO}_{2}+\mathrm{HO}_{2}$ and $\mathrm{RO}_{2}+\mathrm{NO}$ chemistry. Thus, most experiments of this type were performed at elevated temperatures $\left(T \sim 40-45^{\circ} \mathrm{C}\right)$ to facilitate the isoprene $\mathrm{RO}_{2}$ isomerization to HPALDs (Crounse et al., 2011), as measured by ToFCIMS. The atmospheric $\mathrm{RO}_{2}$ fates were qualitatively deduced by observations of their respective products during SOAS (forthcoming papers) and during other campaigns (Paulot et al., 2009b; Wolfe et al., 2011; Beaver et al., 2012).

The fate of HPALDs is not known, but has been suggested as being strongly influenced by photolysis based on reactions of chemical analogs (Wolfe et al., 2012). After the slow chemistry period, $20-100 \%$ lights were turned on in order to diagnose the effects of direct photolysis and $\mathrm{OH}$ oxidation on the product compounds, which is especially instructive when coupled with photochemical modeling. Table 2 reports conditions only for the $\leq 1 \%$ light period and the $20 \%$ light period due to availability of hydrocarbon decay data. When $\mathrm{CH}_{3} \mathrm{ONO}$ experiments were performed with higher light flux from the start, the NO-to- $\mathrm{HO}_{2}$ reactivities were still competitive, but the $\mathrm{OH}$ mixing ratios were higher. These experiments were performed with isoprene, $\alpha$-pinene, and trans $\beta$-IEPOX precursors.

e. Ozonolysis (Exp. 6, 14, 23, and 29): ozonolysis reactions were performed in the dark, with and without the use of excess cyclohexane (50 ppmv) as a scavenger for $\mathrm{OH}$ (Atkinson, 1995). Ozone reacts with isoprene and $\alpha$-pinene with rate coefficients of $k_{\mathrm{ISO}+\mathrm{O}_{3}}=1.3 \times 10^{-17} \mathrm{molec} \mathrm{cm}^{-3}$ and $k_{\alpha-\mathrm{PIN}+\mathrm{O}_{3}}=9.0 \times 10^{-17}$ molec cm $\mathrm{cm}^{-3}$ at $298 \mathrm{~K}$, respectively (Atkinson et al., 2006). After the first few steps of the reaction, however, little agreement exists in the literature for product yields, product distribution, or rate coefficients stemming from reactions of stabilized Criegee intermediates (sCI). This may be due to the large differences among studies in the hydrocarbon loadings $\left([\mathrm{ISO}]_{i}=40-10000 \mathrm{ppbv}\right.$ ), ozone-to-isoprene ratios $(<0.5$ to $>100)$, water vapor content $(<10$ 20000 ppmv), reaction pressures (4-760 torr), analytical methods used for product analysis (GC, HPLC, FTIR, direct $\mathrm{OH}$ vs. scavenging, etc.), and methods used to generate $\mathrm{SCI}\left(\mathrm{CH}_{2} \mathrm{I}_{2}+h v\right.$ vs. gas-phase ozonolysis) (Simonaitis et al., 1991; Neeb et al., 1997; Sauer et al., 1999; Hasson et al., 2001; Kroll et al., 2002; Johnson and Marston, 2008; Drozd and Donahue, 2011; Welz et al., 2012; Huang et al., 2013).

We designed the ozonolysis experiments to have similar ozone-to-isoprene ratios to those observed during SOAS ( $\sim 5-7)$, and performed the experiments under dry (RH $\sim 4 \%$ ) and moderately humid (RH $\sim 50 \%$ ) conditions. The ozonolysis experiments at FIXCIT primarily focused on studying unimolecular and bimolecular chemistry of sCI that affects the yields of $\mathrm{OH}$, hydroperoxides, organic acids, aldehydes and ketones under humid vs. dry conditions. These experiments represent the first coupling between direct $\mathrm{OH}$ observations from GTHOS, aldehyde/ketone measurements from GCFID and SRI-ToFMS, online formaldehyde measurements from FormLIF, and online hydroperoxide measurements from the various CIMS instruments present to provide the most comprehensive picture thus far on the humidity-dependent ozonolysis of isoprene.

f. Competitive $\mathrm{HO}_{2}$ nitrate $\left(\mathrm{NO}_{3}\right)$ oxidation (Exp. 9 and 13): the $\mathrm{NO}_{3}$-initiated experiments during the campaign were performed in the dark, under dry conditions. Excess formaldehyde ([HCHO $]_{i} \sim 4-8$ ppmv) was used as a dark $\mathrm{HO}_{2}$ precursor in order to elevate the contributions of $\mathrm{RO}_{2}+\mathrm{HO}_{2}$ reactions in the $\mathrm{NO}_{3}$ chemistry:

$$
\begin{aligned}
& \mathrm{O}_{3}+\mathrm{NO}_{2} \rightarrow \mathrm{NO}_{3}+\mathrm{O}_{2} \\
& \mathrm{HCHO}+\mathrm{NO}_{3} \rightarrow \mathrm{HNO}_{3}+\mathrm{HCO} \\
& \mathrm{HCO}+\mathrm{O}_{2} \rightarrow \mathrm{CO}+\mathrm{HO}_{2} \\
& \mathrm{HO}_{2}+\mathrm{NO}_{2} \mathrm{HO}_{2} \mathrm{NO}_{2} \\
& \mathrm{NO}_{2}+\mathrm{NO}_{3} \leftrightarrows \mathrm{N}_{2} \mathrm{O}_{5} .
\end{aligned}
$$

This process produces an $\mathrm{HO}_{2} / \mathrm{NO}_{3}$ ratio of approximately 2 (determined by photochemical modeling from the mechanism described in Paulot et al., 2009), a ratio more relevant to the troposphere during nighttime 
oxidation. As $\alpha$-pinene has a higher $\mathrm{NO}_{3}$ loss rate compared to isoprene, a factor of 2 greater mixing ratio of initial formaldehyde was used. The consequence of the experimental design is that the isoprene nitrooxy hydroperoxide (INP) and monoterpene nitrooxy hydroperoxide (MTNP) are major products, in contrast to experiments performed under $\mathrm{RO}_{2}+\mathrm{RO}_{2}$ or $\mathrm{RO}_{2}+\mathrm{NO}_{3}$ dominated conditions ( $\mathrm{Ng}$ et al., 2008; Perring et al., 2009; Kwan et al., 2012). The focus of these experiments was the quantification of INP and MTNP with the various CIMS and with TDLIF, and further exploration of their loss channels to $\mathrm{OH}$ oxidation (simulating sunrise) or to dry AS seed particles by measuring organic aerosol growth on the ToF-AMS. These experiments were performed with isoprene and $\alpha$-pinene precursors.

g. High $\mathrm{NO}_{2} / \mathrm{NO}$ photooxidation (Exp. 26 and 30): the high $\mathrm{NO}_{2}$-to-NO ratios in the lower troposphere in most regions of the globe favor the production of acylperoxy nitrates (APNs) from the $\mathrm{OH}$-initiated reaction of aldehydes like methacrolein and pinonaldehyde (Bertman and Roberts, 1991; Nozière and Barnes, 1998). Unlike the APN from methacrolein (MPAN), the APN from pinonaldehyde has never been measured in the atmosphere (Nouaime et al., 1998; Roberts et al., 1998; Wolfe et al., 2009). The OH oxidations of aldehydes were performed with an $\mathrm{NO}_{2} / \mathrm{NO}$ ratio greater than 10 , and $\mathrm{NO}_{2}$ was replenished as it was reacted away. These reactions were initiated by $\mathrm{CH}_{3} \mathrm{ONO}$ photolysis under higher light flux, producing $[\mathrm{OH}]$ greater than $3 \times 10^{6} \mathrm{molec}^{-3}$. Certain APNs were monitored with ToFCIMS, and total peroxy nitrates ( $\Sigma \mathrm{PNs}$ ) were monitored with TDLIF. A major focus of the high$\mathrm{NO}_{2}$ experiments was to investigate the SOA-formation potential and mechanisms from atmospherically relevant APNs, which is expanded in $\mathrm{h}$.

h. SOA-formation chemistry (Exp. 19, 24, 26, and 30): experiments aimed specifically at studying chemistry leading to SOA formation have overlapping goals with those described above. One focus was the evaluation of the SOA-formation route from APNs by the proposed dioxo ketone, lactone, and epoxide mechanisms (Chan et al., 2010; Kjaergaard et al., 2012; Lin et al., 2013), none of which has yet been validated by independent studies. However, the proposed epoxide chemistry has been integrated into some studies published soon after the proposal by Lin et al. (2013) (Worton et al., 2013; Pye et al., 2013). After MPAN was formed from the high- $\mathrm{NO}_{2}$ reaction of $\mathrm{MAC}+\mathrm{OH}$, a synthesized standard of methacrylic acid epoxide (MAE, provided by the UNC group), the proposed epoxide intermediate, was added to discern the SOA-forming potential of MAE vs. other reactive intermediates in the
MPAN reaction. Following the injection and stabilization of MAE, water vapor was added until the reaction mixture reached $\sim 40 \% \mathrm{RH}$. Then wet AS seeds were injected to investigate any SOA mass growth, as quantified by ToF-AMS.

SOA formation from ISOPN high-NO photooxidation and isoprene low-NO photooxidation products were investigated in the presence of wet AS seeds (40-50\% particle liquid water by volume), meant to simulate the high particle liquid water and sulfate quantities during SOAS. For these experiments, the chambers were humidified to $40-50 \% \mathrm{RH}$, and hydrated AS particles were injected through a wet-wall denuder so that the seed particles retain liquid water above the efflorescence point of AS (Biskos et al., 2006). In the ISOPN high-NO photooxidation, the potential for forming organics that will likely condense onto seed particles, e.g., dinitrates and IEPOX, was recently suggested (L. Lee et al., 2014; Jacobs et al., 2014). The dinitrate pathway was investigated as a potential source of particle-phase organic nitrogen. In the low-NO isoprene photooxidation, IEPOX reactive uptake onto acidic $\mathrm{Mg}_{2} \mathrm{SO}_{4}$ particles (Lin et al., 2012) and non-acidified AS particles (Nguyen et al., 2014), both with non-zero liquid water content, were recently demonstrated. We focused on AS particles with no added acid. The impact of the partitioning of IEPOX on the gas-phase mixing ratios was examined as a potential reason for the differences in observed IEPOX in dry and humid regions.

i. Cross-calibrations (Exp. 4a, 5a, 24, 27, and 30): newly commercially available negative-ion CIMS (Junninen et al., 2010; B. H. Lee et al., 2014) may become common tools for monitoring complex OVOCs in the atmosphere, similarly to the widespread adoption of positive ion CIMS (PTR-MS-based instruments). Some of the new negative ion CIMS instruments were deployed for the first time in field campaigns occurring in recent years. During FIXCIT, synthesized standards of eight isomer-specific compounds were available for cross calibrations with different CIMS in order to better understand the chemical sources of ambient signals during SOAS and in other field campaigns. Table 3 shows the structures, abbreviations, and contributors of the synthesized chemicals. The TripCIMS and the GC-ToFCIMS separated structural isomers through collision-induced dissociation (CID) and through chromatography, respectively. Figure 3 shows a GC-ToFCIMS separation of isomers of the ISOPN synthesized standards, as well as ISOPNs present in a complex photooxidation mixture. SRI-ToFMS and IACIMS tested the switchable reagent ion sources for preferential detection of one or more isomers of compounds with the same molecular formula. 
For certain cross-calibration experiments, standards were injected into an inflatable pillow bag $(\sim 0.2-$ $0.3 \mathrm{~m}^{3}$ ) that was filled with dry $\mathrm{N}_{2}$ to a known volume. The purities of the standards were quantified by nuclear magnetic resonance (NMR) or Fourier transform infrared spectrometry (FT-IR). The injected material was measured by vapor pressure, quantitative volume transfer, or by ToFCIMS and TripCIMS that were calibrated using techniques described elsewhere (Garden et al., 2009; Paulot et al., 2009a; L. Lee et al., 2014; Bates et al., 2014). Some experiments, such as the IEPOX photooxidation experiment, also served a dual purpose for cross-calibration. For example, trans $\beta$-IEPOX was injected into a clean chamber and instruments were allowed to sample for $\sim 1 \mathrm{~h}$ to crosscalibrate before an oxidant precursor was injected. Both LIF-OHR and CRM-OHR were able to measure the $\mathrm{OH}$ reactivity of these OVOC compounds individually, which aids in determining the known and unknown $\mathrm{OH}$ reactivity in ambient environments.

j. GTHOS test experiments: the $\mathrm{OH}$ interference in GTHOS, and possibly other gas-expansion LIF techniques, has been shown to bias $\mathrm{OH}$ measurements systematically high in some biogenically influenced areas unless chemical zeroing was performed (Mao et al., 2012). The excess OH was demonstrated not to be produced by the GTHOS laser itself $(308 \mathrm{~nm})$, but rather, more likely, in the low-pressure flow zone within the nozzle of the instrument. During FIXCIT, several hypotheses proposed by Mao et al. (2012), and some original proposals based on field observations, were tested. The interference precursor candidates were: (i) ozonolysis intermediates - tested with ozonolysis experiments and with ozone injection into the GTHOS inlet; (ii) biogenic peroxides like ISOPOOH or HMHP - tested with synthesized standards; (iii) background chemistry such as $\mathrm{NO}_{2}+\mathrm{O}_{3}$ - tested by the nitrate-oxidation experiment and by sequential injection of $\mathrm{NO}_{2}$ and $\mathrm{O}_{3}$ separately; (iv) dry and humid $\mathrm{HO}_{2}+\mathrm{O}_{3}$ reaction - tested by formaldehyde photolysis with ozone injection during a separate experiment $(01 / 02 / 2014$, not shown in Table 2); (v) beta-hydroxy $\mathrm{RO}_{2}$ radicals formed from $\mathrm{OH}+$ alkene - tested with the photooxidation of 2-methyl-2-butanol and compared with 2,2-dimethylbutane (02/02/2014 and 31/01/2014, not shown in Table 2); and (vi) heat-mediated decomposition of thermally unstable species - tested by temperature ramping to $35-40{ }^{\circ} \mathrm{C}$ inside the chamber. Often, single variables (like ozone or heat) were isolated by incremental additions toward the end of an experiment.

The experiments not described in Table 2 (to test iv and v) were performed after the formal experiments; thus, not all investigators were present. Only GTHOS, ToFCIMS, TripCIMS, ToF-AMS, GCFID, $\mathrm{O}_{3}$ monitor

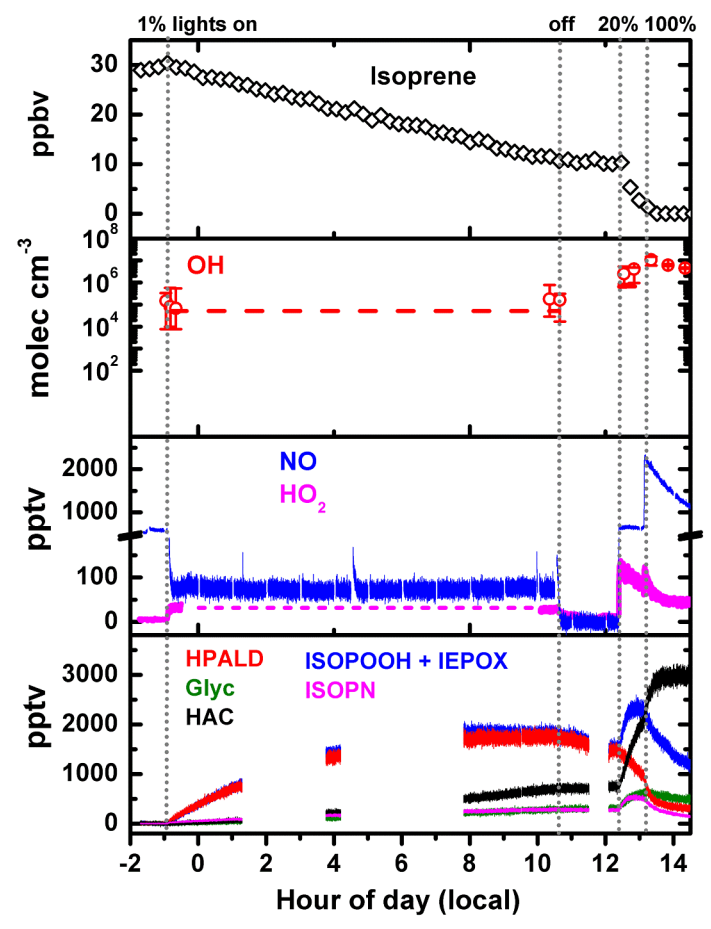

Figure 3. Progress of the slow chemistry experiment performed on 01/07/2014. Isoprene data were provided by GCFID. The red dashed line in the $\mathrm{OH}$ plot is the steady-state $\mathrm{OH}$ concentration derived from the decay of isoprene as monitored by GCFID. $\mathrm{OH}$ and $\mathrm{HO}_{2}$ preliminary data were provided by GTHOS, using chemical zeroing, although the steady-state value of $(0.4-$ 1) $\times 10^{5}$ molec $\mathrm{cm}^{-3}$ was below the detection limit of GTHOS. OH preliminary data were averaged to reduce noise. NO data were provided by NO-CL and OVOC data were provided by ToFCIMS.

and $\mathrm{NO}_{\mathrm{x}}$ monitor were collecting data. The $\mathrm{HO}_{2}+\mathrm{O}_{3}$ test experiment $(01 / 02 / 2014)$ was performed by injecting $\sim 600 \mathrm{ppbv}$ of ozone, then $\sim 50 \mathrm{ppbv}$ of cyclohexane as an $\mathrm{OH}$ tracer for CIMS (monitored by the formation of cyclohexyl hydroperoxide). UV lights were turned on and then 4 ppmv of formaldehyde was injected, which photolyzed to produce $550 \mathrm{pptv}$ of $\mathrm{HO}_{2}$. The $\mathrm{HO}_{2}$ reaction with formaldehyde produced a small yield of HMHP (Niki et al., 1980). Water vapor was injected to diagnose the effect of humidity. Experiments to test the effects of $\mathrm{RO}_{2}$ structure utilized $\mathrm{CH}_{3} \mathrm{ONO}$ to oxidize $\sim 50$ ppbv of either 2-methyl-2-butanol and 2,2dimethylbutane with $\mathrm{OH}$. Ozone $(\sim 600 \mathrm{ppbv})$, water vapor (until $\mathrm{RH} \sim 30-40 \%$ ), and $\mathrm{NO}_{2}$ (400 ppbv) were added sequentially at toward the end of the photooxidation. Finally severally hundred ppb of NO was added to titrate away the ozone.

\subsection{Analytical challenges}

Throughout the campaign, several sources of analytical interferences or systematic biases were discovered. Some chal- 
Table 3. List of contributed synthesized chemical standards for experiments and calibration.

\begin{tabular}{|c|c|c|c|c|c|}
\hline Synthesized standard & PIs & Institutions & $\begin{array}{l}\text { Molecular } \\
\text { structure }\end{array}$ & Atmos. relevance & Synthesis ref. \\
\hline $\begin{array}{l}\text { Isoprene 1-hydroxy } \\
\text { 2-hydroperoxide }(1,2- \\
\text { ISOPOOH) }\end{array}$ & F. N. Keutsch & UWM & & $\begin{array}{l}\text { Major first-gen. } \\
\text { low-NO isoprene }+ \\
\text { OH product }\end{array}$ & $\begin{array}{l}\text { Rivera et } \\
\text { al. (2014) }\end{array}$ \\
\hline $\begin{array}{l}\text { Isoprene 3-hydroxy } \\
\text { 4-hydroperoxide } \\
(3,4 \text {-ISOPOOH) }\end{array}$ & F. N. Keutsch & UWM & & $\begin{array}{l}\text { Major first-gen. } \\
\text { low-NO isoprene }+ \\
\text { OH product }\end{array}$ & $\begin{array}{l}\text { Rivera et } \\
\text { al. (2014) }\end{array}$ \\
\hline $\begin{array}{l}\text { Trans isoprene } \\
\text { 2-epoxydiol } \\
\text { (trans } \beta \text {-IEPOX) }\end{array}$ & $\begin{array}{l}\text { P. O. Wennberg and } \\
\text { J. H. Seinfeld }\end{array}$ & Caltech & & $\begin{array}{l}\text { Major second-gen. } \\
\text { low-NO isoprene }+ \\
\text { OH product }\end{array}$ & $\begin{array}{l}\text { Bates et } \\
\text { al. }(2014)\end{array}$ \\
\hline $\begin{array}{l}\text { Cis isoprene } \\
\text { 2-epoxydiol } \\
\text { (cis } \beta \text {-IEPOX) }\end{array}$ & $\begin{array}{l}\text { P. O. Wennberg and } \\
\text { J. H. Seinfeld }\end{array}$ & Caltech & & $\begin{array}{l}\text { Major second-gen. } \\
\text { low-NO isoprene }+ \\
\text { OH product }\end{array}$ & $\begin{array}{l}\text { Bates et } \\
\text { al. }(2014)\end{array}$ \\
\hline $\begin{array}{l}\text { Isoprene 4-hydroxy 3- } \\
\text { nitrate (4,3-ISOPN) }\end{array}$ & $\begin{array}{l}\text { R. C. Cohen, } \\
\text { P. B. Shepson, } \\
\text { A. S. Hasson, and } \\
\text { P. O. Wennberg }\end{array}$ & $\begin{array}{l}\text { UCB, Purdue Univ., } \\
\text { CSU Fresno (CSUF), } \\
\text { and Caltech }\end{array}$ & & $\begin{array}{l}\text { Major first-gen. } \\
\text { high-NO isoprene }+ \\
\text { OH product }\end{array}$ & $\begin{array}{l}\text { Lee et } \\
\text { al. }(2014 b)\end{array}$ \\
\hline $\begin{array}{l}\text { Isoprene 2-hydroxy } \\
\text { 1-nitrate (2,1-ISOPN) }\end{array}$ & A. S. Hasson & CSUF & & $\begin{array}{l}\text { Minor first-gen. } \\
\text { high-NO isoprene }+ \\
\text { OH product }\end{array}$ & N/A \\
\hline Pinonaldehyde & $\begin{array}{l}\text { P. O. Wennberg and } \\
\text { J. H. Seinfeld }\end{array}$ & Caltech & & $\begin{array}{l}\text { Major first-gen. } \\
\alpha \text {-Pinene }+\mathrm{OH} \text { and } \\
\mathrm{O}_{3} \text { product }\end{array}$ & $\begin{array}{l}\text { Griesbaum et } \\
\text { al. (1997) }\end{array}$ \\
\hline $\begin{array}{l}\text { Methacrylic acid } \\
\text { epoxide (MAE) }\end{array}$ & $\begin{array}{l}\text { J. D. Surratt and } \\
\text { A. Gold }\end{array}$ & $\begin{array}{l}\text { Univ. of NC } \\
\text { Chapel Hill (UNC) }\end{array}$ & $\mathrm{ApH}_{\mathrm{OH}}^{\mathrm{O}}$ & $\begin{array}{l}\text { Minor product } \\
\text { and possible } \mathrm{SOA} \\
\text { precursor from } \\
\mathrm{MAC}+\mathrm{OH}+\mathrm{NO}_{2} \\
\text { reaction }\end{array}$ & $\begin{array}{l}\text { Lin et } \\
\text { al. (2013) }\end{array}$ \\
\hline
\end{tabular}

lenges resulted from the integration of field instruments to a chamber setting, where high concentrations of certain chemicals were used to engineer extremely specific conditions. Thus, these issues do not affect ambient sampling. For example, (1) high $\mathrm{NO}_{2}$ levels in some experiments affected the normal operation of TDLIF because the $\Sigma$ ANs and $\Sigma$ PNs measurements were determined by subtraction of $\mathrm{NO}_{2}$. When $\mathrm{NO}_{2}$ is much higher than $\Sigma$ ANs and $\Sigma \mathrm{PNs}$, the measurement by difference contains large uncertainties; (2) high $\mathrm{H}_{2} \mathrm{O}_{2}$ for low-NO conditions affected the operation of some CIMS instruments because the ppmv mixing ratios of $\mathrm{H}_{2} \mathrm{O}_{2}$ depleted a non-negligible quantity of reagent ions. In order to correct for this, the CIMS instruments needed to calibrate as a function of $\mathrm{H}_{2} \mathrm{O}_{2}$ in addition to traditional methods, or account for the true reagent ion signal (which was anti-correlated with $\mathrm{H}_{2} \mathrm{O}_{2}$ concentration). High $\mathrm{H}_{2} \mathrm{O}_{2}$ also affected GTHOS due to photolysis-derived $\mathrm{OH}$ production by the laser. GTHOS corrected for this effect by removing the $\mathrm{OH}$ background that was determined by sampling when only $\mathrm{H}_{2} \mathrm{O}_{2}$ was present; (3) High formaldehyde, cyclohexane, or $\mathrm{H}_{2} \mathrm{O}_{2}$ dominated the $\mathrm{OH}$ reactivity for certain experiments. In experiments where ppmv levels of volatile compounds were used, LIF-OHR and CRM-OHR did not operate. In contrast, high ozone and NO levels did not appear to affect the operation of any instruments. Temperature and humidity effects on ion sensitivities have been corrected for by ToFCIMS and TripCIMS as standard procedure. Other CIMS are actively characterizing these effects for analytes of interest.

However, other analytical challenges were not unique to laboratory studies. It was found that chemical artifacts were produced from the decomposition of multifunctional OVOC (e.g., ISOPN, ISOPOOH, IEPOX, and pinonaldehyde) under normal operating conditions in some instruments; thus, possibly affecting ambient sampling and field data interpretation. Scheme 2 shows the proposed decomposition pathways of certain isomers of isoprene-derived OVOC to form MAC and MVK. We are aware of MAC and MVK interfer- 


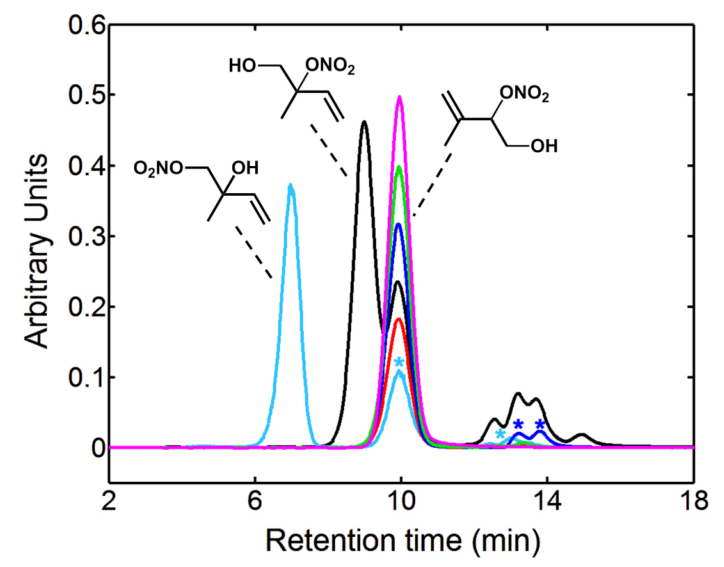

Figure 4. GC-ToFCIMS chromatogram of ISOPNs from an isoprene high-NO photooxidation experiment (black), and from the introduction of 2,1-ISOPN standard synthesized by CSUF (cyan) and 4,3-ISOPN standards synthesized by Caltech (magenta), CSUF (green), UCB (blue), and Purdue (red). The rightmost four peaks apparent in the photooxidation chromatogram are preliminarily identified as the cis and trans 1,4-ISOPN and cis and trans 4,1-ISOPN, although the elution order is not clear. Asterisks $\left(^{*}\right)$ denote impurities in synthesized samples of corresponding color.
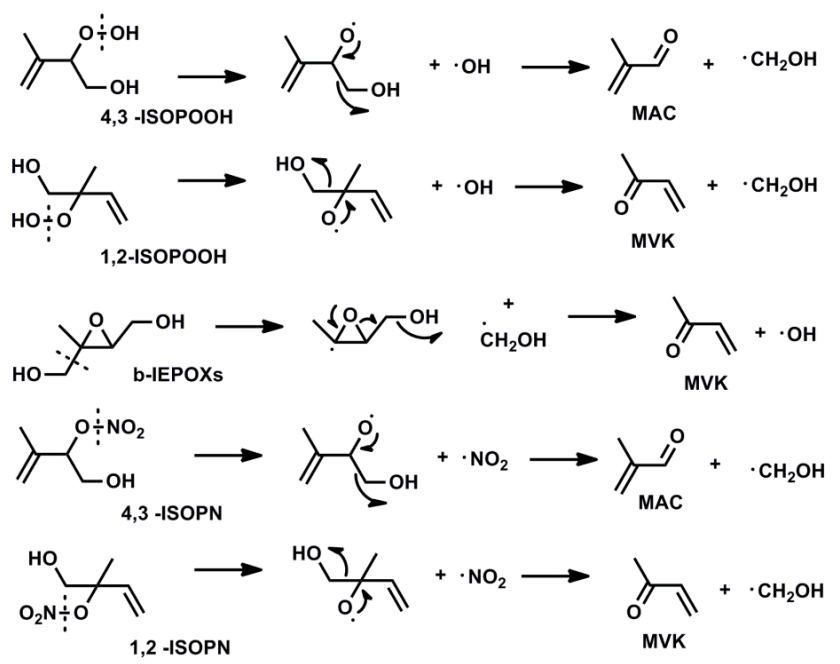

Scheme 2. Select proposed mechanism for the decomposition of OVOCs to carbonyls on contact with metal surfaces or high ionization energies within instrumentation. Other decomposition pathways likely exist and the branching ratios are dependent on instrument operation conditions. Cleavage sites are indicated by dashed lines.

ence only from the 1,2- and 4,3- isomers of ISOPOOH, the 1,2- and 4,3- isomers and ISOPN, and the beta isomers of IEPOX (i.e., the peroxide, nitrate, and epoxide groups are secondary or tertiary). Unfortunately, these isomers are expected to be the most abundant in the atmosphere, e.g., the beta IEPOXs are estimated to represent more than $97 \%$ of atmospheric IEPOX (Bates et al., 2014). The extent of decom- position and product distribution may also vary based on the operating conditions of the particular analytical method. In general, the decomposition was exacerbated by instruments with harsher sampling conditions, i.e., high ionization energy (e.g., the standard $\mathrm{H}_{3} \mathrm{O}^{+}$mode of SRI-ToFMS), high temperatures, and/or materials incompatible with organics (e.g., the hot stainless steel sample loop and inlet of GCFID). OVOCs from the low-NO isoprene photooxidation have been shown to decompose to MAC and MVK in commercial PTRMS instruments (Liu et al., 2013), but the exact identities of the compounds were unclear. During FIXCIT, it was observed that ISOPOOH, IEPOX, and pinonaldehyde were detected at $m / z 71.050$ in the SRI-ToFMS in PTR mode (the sum of MAC + MVK). Switchable reagent ions show promise for removing certain biases, but more work is needed to characterize the chemistry that forms interfering ions. Furthermore, we observed that the decomposition interference also affected GCFID, the other commonly used detection method for MAC and MVK in ambient samples. ISOPOOH, IEPOX, and ISOPN were detected as either MAC or MVK in the GCFID, depending on the specific isomer. The interferences may not be localized to this particular GCFID, and a more detailed account is forthcoming (Rivera et al., 2014). Conversion efficiencies of OVOCs to the $\mathrm{C}_{4}$ carbonyls in the Caltech GCFID range in order of ISOPOOH > IEPOX > ISOPN, and can be almost quantitative for ISOPOOH because of the facile cleavage of the weak O-O bond. Lastly, ISOPN were found to be converted to NO with a small yield in the NO-CL and a larger yield in commercial $\mathrm{NO}_{\mathrm{x}}$ analyzers.

All decomposition-derived artifacts can be avoided by collecting the air sample through a length of tubing submerged in a cold bath $\left(-40^{\circ} \mathrm{C}\right)$, which trapped OVOCs that are less volatile than authentic MAC and MVK. Liu et al. (2013) implemented this technique successfully in their laboratory study using SRI-ToFMS, resulting in a lower yield than previously reported for MAC and MVK in the low-NO oxidation of isoprene. Field application may prove more challenging, however, as the trapping is labor intensive and requires careful humidity control to avoid ice buildup and blockage. During FIXCIT, both GCFID and SRI-ToFMS employed trapping techniques at various times to avoid biases in the detection and interpretation of MAC and MVK data.

\section{Preliminary results and atmospheric implications}

Forthcoming papers will discuss campaign results in detail. Here, we summarize a few interesting observations that appeared to be robust, based on preliminary data analysis of the laboratory and field work.

- Nighttime chemistry of alkenes, as controlled by the $\mathrm{NO}_{3}$ radical, leads to several organic nitrates that are unique compared to daytime high-NO photooxidation. A significant product is the nitrooxy hydroperoxide, the atmospheric importance of which has likely been sig- 
nificantly underestimated in past chamber studies. The nitrooxy hydroperoxide reacts further in the daytime through a currently unknown mechanism.

- The high-NO hydroxy nitrate yield from isoprene is closer to the high end of the spectrum (range 4-15\%), important for the accurate simulations of volatile nitrogen in the atmosphere.

- Observed mixing ratios of isoprene low-NO photooxidation products are impacted by heterogeneous chemistry that appears to be mediated by aqueous processes, which has implications for the interpretation of IEPOX observations in dry vs. humid areas of the world.

- Environmental conditions in many locations, including within a biomass burning plume, are favorable for the $\mathrm{H}$-shift $\mathrm{RO}_{2}$ isomerization chemistry that produces compounds like HPALDs and very low-volatility oxygenates. The atmospheric fate of HPALDs is highly impacted by direct photolysis that recycles $\mathrm{OH}$, as well as other complex chemistry and physical processes.

- The ozonolysis reaction of isoprene produces a high yield of $\mathrm{C}_{1}$ compounds that are also observed with considerable abundance during ambient sampling. The hydroperoxide and acid yields appear to be underestimated by previous studies that detected these compounds via offline techniques. The $\mathrm{OH}$ yield may not follow the same trend with $\mathrm{RH}$ as the hydroperoxide and acid yields.

- APNs are efficient SOA precursors. SOA formation was prompt, and organic mass growth occurred quickly without the addition of inorganic seeds, i.e., the SOA intermediate(s) from APN $+\mathrm{OH}$ condensed onto predominantly organic SOA material. Injections of the MAE standard did not increase the SOA mass growth.

- Several experiments produced significant amounts of excess $\mathrm{OH}$, as measured by the GTHOS instrument, providing further avenues for investigation. These experiments also ruled out several candidates for the $\mathrm{OH}$ interference. More work is underway to characterize the phenomenon comprehensively.

- Calibrations with several synthesized standards of OVOC (Table 3) significantly aid in data interpretation from OHR and new CIMS instruments. Sampling these OVOC through standard instrumentation may interfere with some routine field and chamber measurements (depends on the run conditions and instrument setup), but may be mediated by cold-trapping methods. This is likely a contributing factor in the high discrepancies in MAC and MVK yields from low-NO isoprene photooxidation previously reported. For example, we find the preliminary low-NO yields of MVK $(6 \pm 3 \%)$ and
MAC ( $4 \pm 2 \%)$, determined by GC-FID, from photooxidation of isoprene are consistent with Liu et al. (2013) when cold-trapping methods were employed (Exp. 21). However, the low-NO "yields" of MVK and MAC are each greater than $40 \%$ when sampled directly by the GC-FID from the chamber (Exp. 2) due to interferences by isomers of ISOPOOH (Rivera et al., 2014) and possibly other OVOCs.

Final data from the FIXCIT campaign will be made publicly available on archives hosted by the US National Oceanic and Atmospheric Administration (NOAA, http://esrl.noaa. gov) in January 2016. Data will be submitted in the ICARTT format, standardized by the US National Aeronautics and Space Administration (NASA, http://www-air.larc.nasa.gov/ missions/etc/IcarttDataFormat.htm).

\section{Summary}

Although data analysis is ongoing, the goals of the FIXCIT campaign appear to have been met during the campaign period. The insights gained from experimental observations under well-controlled laboratory conditions have already proved valuable for understanding ambient observations from SOAS. The community effort to pursue atmospherically important chemistry with sensitive ambient techniques and custom-synthesized chemicals has elevated our understanding of atmospheric oxidation for a number of biogenic compounds. Novel mechanistic information obtained during FIXCIT will be helpful to update chemical mechanisms currently implemented in large-scale chemistrycoupled transport models. Instrumental inter-comparisons, an important aspect of the campaign, have demonstrated that a thorough characterization of new and standard ambient sampling techniques using authentic standards is necessary for accurate data interpretation.

Chamber experiments are clearly invaluable to the field of atmospheric chemistry, as the results feed directly into models that are used to ascertain regional and global climate and chemistry feedbacks. Furthermore, chamber data aid in the interpretation of complex results obtained from field studies. However, it can be difficult to decipher the conditions under which chamber experiments are most relevant, and a standard protocol for data reporting may be needed. For example, best estimates of oxidation conditions in chambers (i.e., if reactions are $\mathrm{HO}_{2}$-dominated, low- $\mathrm{NO}$ but $\mathrm{RO}_{2}$-dominated, high-NO, high- $\mathrm{NO}_{\mathrm{x}}$ but low-NO, and so on) would greatly aid in comparisons of these experiments and others. The experiments in this campaign were fundamentally focused on the fate of the $\mathrm{RO}_{2}$ radical as a delineation between chemical regimes. FIXCIT experiments (Table 2) can be further improved or tailored to the specific needs of the scientist. It has been demonstrated, here and elsewhere, that chamber studies that include chemistry representative of the atmosphere and well-characterized instrumental methods can accurately 
reproduce observations in the ambient environment. The results from FIXCIT make a case for future synergistic integration of laboratory studies with field campaigns, which maximizes the level of mechanistic understanding and data confidence obtained from the combination of both types of studies.

Acknowledgements. We acknowledge the collaborative efforts of FIXCIT participants (Tables 2 and 3), as well as the organizers and logistics personnel for SOAS 2013. FIXCIT was made possible by the support from multiple agencies: the US National Science Foundation (NSF) under grants AGS-1240604 (Caltech), AGS-1246918 (PSU), AGS-1247421 (UWM), AGS-1243354 (CU/ARI), AGS-1240611 (CSU), and AGS-1120076 (UCB); the US Department of Energy under grant DE-SC0006626 (Caltech); and the US Environmental Protection Agency (EPA) under STAR grant 835407 (PNNL/UCB/SUNY). T. B. Nguyen (Caltech) was supported by the NSF Postdoctoral Research Fellowship program, award AGS-1331360. NCAR is operated under the sponsorship of the NSF.

Edited by: N. L. Ng

\section{References}

Anglada, J. M., Gonzalez, J., and Torrent-Sucarrat, M.: Effects of the substituents on the reactivity of carbonyl oxides. A theoretical study on the reaction of substituted carbonyl oxides with water, Phys. Chem. Chem. Phys., 13, 13034-13045, doi:10.1039/c1cp20872a, 2011.

Atkinson, R. and Carter, W. P. L.: Kinetics and mechanisms of the gas-phase reactions of ozone with organic compounds under atmospheric conditions, Chem. Rev., 84, 437-470, 1984.

Atkinson, R. and Arey, J.: Gas-phase tropospheric chemistry of biogenic volatile organic compounds: A review, Atmospheric Environment, 37, 197-219, 2003.

Atkinson, R., Carter, W. P., Winer, A. M., and Pitts Jr, J. N.: An experimental protocol for the determination of $\mathrm{OH}$ radical rate constants with organics using methyl nitrite photolysis as an $\mathrm{OH}$ radical source, J. Air Pollut. Contr. Assoc., 31, 1090-1092, 1981.

Atkinson, R., Tuazon, E. C., and Aschmann, S. M.: Products of the gas-phase reactions of $\mathrm{O}_{3}$ with alkenes Environ. Sci. Technol., 29, 1860-1866, 1995.

Atkinson, R., Baulch, D. L., Cox, R. A., Crowley, J. N., Hampson, R. F., Hynes, R. G., Jenkin, M. E., Rossi, M. J., Troe, J., and Subcommittee, I.: Evaluated kinetic and photochemical data for atmospheric chemistry: Volume II - gas phase reactions of organic species, Atmos. Chem. Phys., 6, 3625-4055, doi:10.5194/acp-63625-2006, 2006.

Bates, K. H., Crounse, J. D., St. Clair, J. M., Bennett, N. B., Nguyen, T. B., Seinfeld, J. H., Stoltz, B. M., and Wennberg, P. O.: Gas phase production and loss of isoprene epoxydiols, J. Phys. Chem. A, 118, 1237-1246, doi:10.1021/jp4107958, 2014.

Beaver, M. R., Clair, J. M. S., Paulot, F., Spencer, K. M., Crounse, J. D., LaFranchi, B. W., Min, K. E., Pusede, S. E., Wooldridge, P. J., Schade, G. W., Park, C., Cohen, R. C., and Wennberg, P. O.: Importance of biogenic precursors to the budget of organic nitrates: Observations of multifunctional organic nitrates by cims and TD-LIF during BEARPEX 2009, Atmos. Chem. Phys., 12, 5773-5785, doi:10.5194/acp-12-5773-2012, 2012.

Becker, K. H., Brockmann, K. J., and Bechara, J.: Production of hydrogen peroxide in forest air by reaction of ozone with terpenes, Nature, 346, 256-258, 1990.

Bertman, S. B. and Roberts, J. M.: A PAN analog from isoprene photooxidation, Geophys. Res. Lett., 18, 1461-1464, 1991.

Biskos, G., Paulsen, D., Russell, L. M., Buseck, P. R., and Martin, S. T.: Prompt deliquescence and efflorescence of aerosol nanoparticles, Atmos. Chem. Phys., 6, 4633-4642, doi:10.5194/acp-64633-2006, 2006.

Brune, W. H., Stevens, P. S., and Mather, J. H.: Measuring OH and $\mathrm{HO}_{2}$ in the troposphere by laser-induced fluorescence at low pressure, J. Atmos. Sci., 52, 3328-3336, doi:10.1175/15200469(1995)052<3328:moahit>2.0.co;2, 1995.

Canagaratna, M. R., Jayne, J. T., Jimenez, J. L., Allan, J. D., Alfarra, M. R., Zhang, Q., Onasch, T. B., Drewnick, F., Coe, H., Middlebrook, A., Delia, A., Williams, L. R., Trimborn, A. M., Northway, M. J., DeCarlo, P. F., Kolb, C. E., Davidovits, P., and Worsnop, D. R.: Chemical and microphysical characterization of ambient aerosols with the aerodyne aerosol mass spectrometer, Mass Spectrom. Rev., 26, 185-222, doi:10.1002/mas.20115, 2007.

Chan, A. W. H., Chan, M. N., Surratt, J. D., Chhabra, P. S., Loza, C. L., Crounse, J. D., Yee, L. D., Flagan, R. C., Wennberg, P. O., and Seinfeld, J. H.: Role of aldehyde chemistry and $\mathrm{NO}_{\mathrm{x}}$ concentrations in secondary organic aerosol formation, Atmos. Chem. Phys., 10, 7169-7188, doi:10.5194/acp-10-7169-2010, 2010.

Claeys, M., Wang, W., Ion, A. C., Kourtchev, I., Gelencser, A., and Maenhaut, W.: Formation of secondary organic aerosols from isoprene and its gas-phase oxidation products through reaction with hydrogen peroxide, Atmos. Environ., 38, 4093-4098, doi:10.1016/j.atmosenv.2004.06.001, 2004.

Criegee, R.: Mechanism of ozonolysis, Angew. Chem., 87, 765-771, 1975.

Crounse, J. D., McKinney, K. A., Kwan, A. J., and Wennberg, P. O.: Measurement of gas-phase hydroperoxides by chemical ionization mass spectrometry, Anal. Chem., 78, 6726-6732, doi:10.1021/ac0604235, 2006.

Crounse, J. D., Paulot, F., Kjaergaard, H. G., and Wennberg, P. O.: Peroxy radical isomerization in the oxidation of isoprene, Phys. Chem. Chem. Phys., 13, 13607-13613, 2011.

Crounse, J. D., Nielsen, L. B., Jørgensen, S., Kjaergaard, H. G., and Wennberg, P. O.: Autoxidation of organic compounds in the atmosphere, J. Phys. Chem. Lett., 4, 3513-3520, doi:10.1021/jz4019207, 2013.

Day, D. A., Wooldridge, P. J., Dillon, M. B., Thornton, J. A., and Cohen, R. C.: A thermal dissociation laser-induced fluorescence instrument for in situ detection of $\mathrm{NO}_{2}$, peroxy nitrates, alkyl nitrates, and $\mathrm{HNO}_{3}$, J. Geophys. Res., 107, 4046, doi:10.1029/2001jd000779, 2002.

DeCarlo, P. F., Kimmel, J. R., Trimborn, A., Northway, M. J., Jayne, J. T., Aiken, A. C., Gonin, M., Fuhrer, K., Horvath, T., Docherty, K., Worsnop, D. R., and Jimenez, J. L. Field-Deployable, HighResolution, Time-of-Flight Aerosol Mass Spectrometer, Anal. Chem., 78, 8281-8289, 2006.

DiGangi, J., Boyle, E., Karl, T., Harley, P., Turnipseed, A., Kim, S., Cantrell, C., Maudlin Iii, R., Zheng, W., and Flocke, F.: First 
direct measurements of formaldehyde flux via eddy covariance: Implications for missing in-canopy formaldehyde sources, Atmos. Chem. Phys., 11, 10565-10578, doi:10.5194/acp-11-105652011, 2011.

Donahue, N. M., Drozd, G. T., Epstein, S. A., Presto, A. A., and Kroll, J. H.: Adventures in ozoneland: Down the rabbit-hole, Phys. Chem. Chem. Phys., 13, 10848-10857, 2011.

Drozd, G. T. and Donahue, N. M.: Pressure dependence of stabilized Criegee intermediate formation from a sequence of alkenes, J. Phys. Chem. A, 115, 4381-4387, doi:10.1021/jp2001089, 2011.

Eddingsaas, N. C., Loza, C. L., Yee, L. D., Seinfeld, J. H., and Wennberg, P. O.: $\alpha$-pinene photooxidation under controlled chemical conditions - Part 1: Gas-phase composition in low- and high- $\mathrm{NO}_{\mathrm{x}}$ environments, Atmos. Chem. Phys., 12, 6489-6504, doi:10.5194/acp-12-6489-2012, 2012.

Ehn, M., Thornton, J. A., Kleist, E., Sipila, M., Junninen, H., Pullinen, I., Springer, M., Rubach, F., Tillmann, R., Lee, B., LopezHilfiker, F., Andres, S., Acir, I.-H., Rissanen, M., Jokinen, T., Schobesberger, S., Kangasluoma, J., Kontkanen, J., Nieminen, T., Kurten, T., Nielsen, L. B., Jorgensen, S., Kjaergaard, H. G., Canagaratna, M., Maso, M. D., Berndt, T., Petaja, T., Wahner, A., Kerminen, V.-M., Kulmala, M., Worsnop, D. R., Wildt, J., and Mentel, T. F.: A large source of low-volatility secondary organic aerosol, Nature, 506, 476-479, doi:10.1038/nature13032, 2014.

Fenske, J. D., Hasson, A. S., Ho, A. W., and Paulson, S. E.: Measurement of absolute unimolecular and bimolecular rate constants for $\mathrm{CH} 3 \mathrm{CHOO}$ generated by the trans-2-butene reaction with ozone in the gas phase, J. Phys. Chem. A, 104, 9921-9932, 2000.

Fuentes, J. D., Lerdau, M., Atkinson, R., Baldocchi, D., Bottenheim, J. W., Ciccioli, P., Lamb, B., Geron, C., Gu, L., Guenther, A., Sharkey, T. D., and Stockwell, W.: Biogenic hydrocarbons in the atmospheric boundary layer: A review, B. Am. Meteorol. Soc., 81, 1537-1575, 2000.

Gäb, S., Hellpointner, E., Turner, W. V., and Korte, F.: Hydroxymethyl hydroperoxide and bis(hydroxymethyl) peroxide from gas-phase ozonolysis of naturally occurring alkenes, Nature, 316 , 535-536, 1985.

Garden, A. L., Paulot, F., Crounse, J. D., Maxwell-Cameron, I. J., Wennberg, P. O., and Kjaergaard, H. G.: Calculation of conformationally weighted dipole moments useful in ion-molecule collision rate estimates, Chem. Phys. Lett., 474, 45-50, 2009.

Griesbaum, K., Dong, Y., and McCullough, K. J.: Ozonolyses of acetylenes: Trapping of a-oxo carbonyl oxides by carbonyl compounds and stabilization of a-oxo ozonides by derivatizations, $\mathrm{J}$. Org. Chem., 62, 6129-6136, 1997.

Griffin, R. J., Cocker, D. R., III, Flagan, R. C., and Seinfeld, J. H.: Organic aerosol formation from the oxidation of biogenic hydrocarbons, J. Geophys. Res., 104, 3555-3567, 1999.

Guenther, A., Hewitt, C. N., Erickson, D., Fall, R., Geron, C., Graedel, T., Harley, P., Klinger, L., Lerdau, M., McKay, W. A., Scholes, B., Steinbrecher, R., Tallamraju, R., Taylor, J., and Zimmerman, P.: A global model of natural volatile organic compound emissions, J. Geophys. Res., 100, 8873-8892, 1995.

Guenther, A. B., Jiang, X., Heald, C. L., Sakulyanontvittaya, T., Duhl, T., Emmons, L. K., and Wang, X.: The model of emissions of gases and aerosols from nature version 2.1 (MEGAN2.1): An extended and updated framework for modeling biogenic emissions, Geosci. Model Dev., 5, 1471-1492, doi:10.5194/gmd-51471-2012, 2012.

Hansel, A., Jordan, A., Holzinger, R., Prazeller, P., Vogel, W., and Lindinger, W.: Proton transfer reaction mass spectrometry: Online trace gas analysis at the ppb level, Int. J. Mass. Spectrom. Ion Proc., 149-150, 609-619, 1995.

Hasson, A. S., Ho, A. W., Kuwata, K. T., and Paulson, S. E.: Production of stabilized Criegee intermediates and peroxides in the gas phase ozonolysis of alkenes 2 . Asymmetric and biogenic alkenes, J. Geophys. Res., 106, 34143-34153, 2001.

Henze, D. K., Seinfeld, J. H., Ng, N. L., Kroll, J. H., Fu, T. M., Jacob, D. J., and Heald, C. L.: Global modeling of secondary organic aerosol formation from aromatic hydrocarbons: Highvs. Low-yield pathways, Atmos. Chem. Phys., 8, 2405-2420, doi:10.5194/acp-8-2405-2008, 2008.

Hoffmann, T., Odum, J. R., Bowman, F., Collins, D., Klockow, D., Flagan, R. C., and Seinfeld, J. H.: Formation of organic aerosols from the oxidation of biogenic hydrocarbons, J. Atmos. Chem., 26, 189-222, 1997.

Hottle, J. R., Huisman, A. J., DiGangi, J. P., Kammrath, A., Galloway, M. M., Coens, K. L., and Keutsch, F. N.: A laser induced fluorescence-based instrument for in-situ measurements of atmospheric formaldehyde, Environ. Sci. Technol., 43, 790-795, doi:10.1021/es801621f, 2008.

Huang, D., Chen, Z., Zhao, Y., and Liang, H.: Newly observed peroxides and the water effect on the formation and removal of hydroxyalkyl hydroperoxides in the ozonolysis of isoprene, Atmos. Chem. Phys, 13, 5671-5683, doi:10.5194/acp-13-56712013, 2013.

Huisman, A. J., Hottle, J. R., Coens, K. L., DiGangi, J. P., Galloway, M. M., Kammrath, A., and Keutsch, F. N.: Laser-induced phosphorescence for the in situ detection of glyoxal at part per trillion mixing ratios, Anal. Chem., 80, 5884-5891, 2008.

Jacobs, M. I., Darer, A. I., and Elrod, M. J.: Rate constants and products of the $\mathrm{OH}$ reaction with isoprene-derived epoxides, Environ. Sci. Technol., 47, 12868-12876, 2013.

Jacobs, M. I., Burke, W. J., and Elrod, M. J.: Kinetics of the reactions of isoprene-derived hydroxynitrates: gas phase epoxide formation and solution phase hydrolysis, Atmos. Chem. Phys., 14, 8933-8946, doi:10.5194/acp-14-8933-2014, 2014.

Johnson, D., and Marston, G.: The gas-phase ozonolysis of unsaturated volatile organic compounds in the troposphere, Chem. Soc. Rev., 37, 699-716, 2008.

Jordan, A., Haidacher, S., Hanel, G., Hartungen, E., Herbig, J., Märk, L., Schottkowsky, R., Seehauser, H., Sulzer, P., and Märk, T.: An online ultra-high sensitivity proton-transferreaction mass-spectrometer combined with switchable reagent ion capability (PTR+ SRI-MS), Int. J. Mass Spectrom., 286, 32-38, 2009.

Junninen, H., Ehn, M., Petäjä, T., Luosujärvi, L., Kotiaho, T., Kostiainen, R., Rohner, U., Gonin, M., Fuhrer, K., Kulmala, M., and Worsnop, D. R.: A high-resolution mass spectrometer to measure atmospheric ion composition, Atmos. Meas. Tech., 3, 10391053, doi:10.5194/amt-3-1039-2010, 2010.

Kjaergaard, H. G., Knap, H. C., Ørnsø, K. B., Jørgensen, S., Crounse, J. D., Paulot, F., and Wennberg, P. O.: Atmospheric fate of methacrolein. 2. Formation of lactone and implications for or- 
ganic aerosol production, J. Phys. Chem. A, 116, 5763-5768, doi:10.1021/jp210853h, 2012.

Kroll, J. H., Clarke, J. S., Donahue, N. M., Anderson, J. G., and Demerjian, K. L.: Mechanism of $\mathrm{HO}_{\mathrm{x}}$ formation in the gas-phase ozone-alkene reaction. 1. Direct, pressure-dependent measurements of prompt OH yields, J. Phys. Chem. A, 105, 1554-1560, 2001.

Kroll, J. H., Donahue, N. M., Cee, V. J., Demerjian, K. L., and Anderson, J. G.: Gas-phase ozonolysis of alkenes: Formation of OH from anti carbonyl oxides, J. Amer. Chem. Soc., 124, 85188519, 2002.

Kuwata, K. T., Hermes, M. R., Carlson, M. J., and Zogg, C. K.: Computational studies of the isomerization and hydration reactions of acetaldehyde oxide and methyl vinyl carbonyl oxide, J. Phys. Chem. A, 114, 9192-9204, doi:10.1021/jp105358v, 2010.

Kwan, A. J., Chan, A. W. H., Ng, N. L., Kjaergaard, H. G., Seinfeld, J. H., and Wennberg, P. O.: Peroxy radical chemistry and $\mathrm{OH}$ radical production during the $\mathrm{NO}_{3}$-initiated oxidation of isoprene, Atmos. Chem. Phys., 12, 7499-7515, doi:10.5194/acp-12-74992012, 2012.

Lee, B. H., Lopez-Hilfiker, F. D., Mohr, C., Kurtén, T., Worsnop, D. R., and Thornton, J. A.: An iodide-adduct high-resolution time-of-flight chemical-ionization mass spectrometer: Application to atmospheric inorganic and organic compounds, Environ. Sci. Technol., 48, 6309-6317, doi:10.1021/es500362a, 2014.

Lee, J. H., Leahy, D. F., Tang, I. N., and Newman, L.: Measurement and speciation of gas phase peroxides in the atmosphere, $\mathrm{J}$. Geophys. Res., 98, 2911-2915, doi:10.1029/92jd02514, 1993.

Lee, L., Teng, A. P., Wennberg, P. O., Crounse, J. D., and Cohen, R. C.: On rates and mechanisms of $\mathrm{OH}$ and $\mathrm{O}_{3}$ reactions with isoprene-derived hydroxy nitrates, J. Phys. Chem. A, 118, 16221637, doi:10.1021/jp4107603, 2014.

Lee, M., Heikes, B. G., and O'Sullivan, D. W.: Hydrogen peroxide and organic hydroperoxide in the troposphere: A review, Atmos. Environ., 34, 3475-3494, doi:10.1016/S1352-2310(99)00432-X, 2000.

Lelieveld, J., Butler, T. M., Crowley, J. N., Dillon, T. J., Fischer, H., Ganzeveld, L., Harder, H., Lawrence, M. G., Martinez, M., Taraborrelli, D., and Williams, J.: Atmospheric oxidation capacity sustained by a tropical forest, Nature, 452, 737-740, doi:10.1038/nature06870, 2008.

Lin, Y.-H., Zhang, Z., Docherty, K. S., Zhang, H., Budisulistiorini, S. H., Rubitschun, C. L., Shaw, S. L., Knipping, E. M., Edgerton, E. S., Kleindienst, T. E., Gold, A., and Surratt, J. D.: Isoprene epoxydiols as precursors to secondary organic aerosol formation: Acid-catalyzed reactive uptake studies with authentic compounds, Environ. Sci. Technol., 46, 250-258, doi:10.1021/es202554c, 2012.

Lin, Y.-H., Zhang, H., Pye, H. O. T., Zhang, Z., Marth, W. J., Park, S., Arashiro, M., Cui, T., Budisulistiorini, S. H., Sexton, K. G., Vizuete, W., Xie, Y., Luecken, D. J., Piletic, I. R., Edney, E. O., Bartolotti, L. J., Gold, A., and Surratt, J. D.: Epoxide as a precursor to secondary organic aerosol formation from isoprene photooxidation in the presence of nitrogen oxides, Proc. Nat. Acad. Sci., 110, 6718-6723, doi:10.1073/pnas.1221150110, 2013.

Liu, Y. J., Herdlinger-Blatt, I., McKinney, K. A., and Martin, S. T.: Production of methyl vinyl ketone and methacrolein via the hydroperoxyl pathway of isoprene oxidation, Atmos. Chem. Phys., 13, 5715-5730, doi:10.5194/acp-13-5715-2013, 2013.
Loza, C. L., Chan, A. W. H., Galloway, M. M., Keutsch, F. N., Flagan, R. C., and Seinfeld, J. H.: Characterization of vapor wall loss in laboratory chambers, Environ. Sci. Technol., 44, 5074-5078, doi:10.1021/es100727v, 2010.

Mao, J., Ren, X., Brune, W. H., Olson, J. R., Crawford, J. H., Fried, A., Huey, L. G., Cohen, R. C., Heikes, B., Singh, H. B., Blake, D. R., Sachse, G. W., Diskin, G. S., Hall, S. R., and Shetter, R. E.: Airborne measurement of OH reactivity during INTEX-B, Atmos. Chem. Phys., 9, 163-173, doi:10.5194/acp-9-163-2009, 2009.

Mao, J., Ren, X., Zhang, L., Van Duin, D. M., Cohen, R. C., Park, J. H., Goldstein, A. H., Paulot, F., Beaver, M. R., Crounse, J. D., Wennberg, P. O., DiGangi, J. P., Henry, S. B., Keutsch, F. N., Park, C., Schade, G. W., Wolfe, G. M., Thornton, J. A., and Brune, W. H.: Insights into hydroxyl measurements and atmospheric oxidation in a california forest, Atmos. Chem. Phys., 12, 8009-8020, doi:10.5194/acp-12-8009-2012, 2012.

Martin, S. T.: Phase transitions of aqueous atmospheric particles, Chem. Rev., 100, 3403-3453, 2000.

Neeb, P., Sauer, F., Horie, O., and Moortgat, G. K.: Formation of hydroxymethyl hydroperoxide and formic acid in alkene ozonolysis in the presence of water vapor, Atmos. Environ., 31, 1417-1423, 1997.

Ng, N. L., Kwan, A. J., Surratt, J. D., Chan, A. W. H., Chhabra, P. S., Sorooshian, A., Pye, H. O. T., Crounse, J. D., Wennberg, P. O., Flagan, R. C., and Seinfeld, J. H.: Secondary organic aerosol (SOA) formation from reaction of isoprene with nitrate radicals $\left(\mathrm{NO}_{3}\right)$, Atmos. Chem. Phys., 8, 4117-4140, doi:10.5194/acp-84117-2008, 2008.

Nguyen, T. B., Coggon, M. M., Bates, K. H., Zhang, X., Schwantes, R. H., Schilling, K. A., Loza, C. L., Flagan, R. C., Wennberg, P. O., and Seinfeld, J. H.: Organic aerosol formation from the reactive uptake of isoprene epoxydiols (IEPOX) onto nonacidified inorganic seeds, Atmos. Chem. Phys., 14, 3497-3510, doi:10.5194/acp-14-3497-2014, 2014.

Niki, H., Maker, P. D., Savage, C. M., and Breitenbach, L. P.: Further ir spectroscopic evidence for the formation of hydroperoxyhydroxymethane in the gas phase reaction of hydroperoxy radical with formaldehyde, Chem. Phys. Lett., 75, 533-535, 1980.

Nouaime, G., Bertman, S., Seaver, C., Elyea, D., Huang, H., Shepson, P., Starn, T., Riemer, D., Zika, R., and Olszyna, K.: Sequential oxidation products from tropospheric isoprene chemistry: MACR and MPAN at a $\mathrm{NO}_{\mathrm{x}}$-rich forest environment in the southeastern United States, J. Geophys. Res., 103, 22463-22471, 1998.

Nozière, B. and Barnes, I.: Evidence for formation of a PAN analogue of pinonic structure and investigation of its thermal stability, J. Geophys. Res., 103, 25587-25597, 1998.

Paulot, F., Crounse, J. D., Kjaergaard, H. G., Kroll, J. H., Seinfeld, J. H., and Wennberg, P. O.: Isoprene photooxidation: New insights into the production of acids and organic nitrates, Atmos. Chem. Phys., 9, 1479-1501, doi:10.5194/acp-9-1479-2009, 2009a.

Paulot, F., Crounse, J. D., Kjaergaard, H. G., Kurten, A., St. Clair, J. M., Seinfeld, J. H., and Wennberg, P. O.: Unexpected epoxide formation in the gas-phase photooxidation of isoprene, Science, 325, 730-733, doi:10.1126/science.1172910, 2009b.

Peeters, J., Nguyen, T. L., and Vereecken, L.: $\mathrm{HO}_{\mathrm{x}}$ radical regeneration in the oxidation of isoprene, Phys. Chem. Chem. Phys., 11, 5935-5939, 2009. 
Perring, A. E., Wisthaler, A., Graus, M., Wooldridge, P. J., Lockwood, A. L., Mielke, L. H., Shepson, P. B., Hansel, A., and Cohen, R. C.: A product study of the isoprene $+\mathrm{NO}_{3}$ reaction, Atmos. Chem. Phys., 9, 4945-4956, doi:10.5194/acp-9-4945-2009, 2009.

Pye, H. O. T., Pinder, R. W., Piletic, I. R., Xie, Y., Capps, S. L., Lin, Y.-H., Surratt, J. D., Zhang, Z., Gold, A., Luecken, D. J., Hutzell, W. T., Jaoui, M., Offenberg, J. H., Kleindienst, T. E., Lewandowski, M., and Edney, E. O.: Epoxide pathways improve model predictions of isoprene markers and reveal key role of acidity in aerosol formation, Environ. Sci. Technol., 47, 1105611064, doi:10.1021/es402106h, 2013.

Ridley, B. and Grahek, F.: A small, low flow, high sensitivity reaction vessel for NO chemiluminescence detectors, J. Atmos. Ocean. Tech., 7, 307-311, 1990.

Rivera-Rios, J. C., Nguyen, T. B., Crounse, J. D., Jud, W., St. Clair, J. M., Mikoviny, T., Gilman, J. B., Lerner, B. M., Kaiser, J. B., de Gouw, J., Wisthaler, A., Hansel, A., Wennberg, P. O., Seinfeld, J. H., and Keutsch, F. N.: Conversion of hydroperoxides to carbonyls in field and laboratory instrumentation: Observational bias in diagnosing pristine versus anthropogenically controlled atmospheric chemistry, Geophys. Res. Lett., 41, doi:10.1002/2014GL061919, 2014.

Roberts, J. M., Williams, J., Baumann, K., Buhr, M. P., Goldan, P. D., Holloway, J., Hübler, G., Kuster, W. C., McKeen, S. A., and Ryerson, T. B.: Measurements of PAN, PPN, and MPAN made during the 1994 and 1995 Nashville intensives of the southern oxidant study: Implications for regional ozone production from biogenic hydrocarbons, J. Geophys. Res., 103, 22473-22490, 1998.

Rollins, A. W., Kiendler-Scharr, A., Fry, J. L., Brauers, T., Brown, S. S., Dorn, H. P., Dubé, W. P., Fuchs, H., Mensah, A., Mentel, T. F., Rohrer, F., Tillmann, R., Wegener, R., Wooldridge, P. J., and Cohen, R. C.: Isoprene oxidation by nitrate radical: Alkyl nitrate and secondary organic aerosol yields, Atmos. Chem. Phys., 9, 6685-6703, doi:10.5194/acp-9-6685-2009, 2009.

Sauer, F., Schäfer, C., Neeb, P., Horie, O., and Moortgat, G. K.: Formation of hydrogen peroxide in the ozonolysis of isoprene and simple alkenes under humid conditions, Atmos. Environ., 33, 229-241, 1999.

Simonaitis, R., Olszyna, K., and Meagher, J.: Production of hydrogen peroxide and organic peroxides in the gas phase reactions of ozone with natural alkenes, Geophys. Res. Lett., 18, 9-12, 1991.

Sinha, V., Williams, J., Crowley, J., and Lelieveld, J.: The comparative reactivity method-a new tool to measure total $\mathrm{OH}$ reactivity in ambient air, Atmos. Chem. Phys., 8, 2213-2227, doi:10.5194/acp-8-2213-2008, 2008.

St. Clair, J. M., McCabe, D. C., Crounse, J. D., Steiner, U., and Wennberg, P. O.: Chemical ionization tandem mass spectrometer for the in situ measurement of methyl hydrogen peroxide, Rev. Sci. Instrum., 81, 094102-094106, 2010.
Surratt, J., Chan, A. W. H., Eddingsaas, N. C., Chan, M., Loza, C. L., Kwan, A. J., Hersey, S. P., Flagan, R. C., Wennberg, P. O., and Seinfeld, J. H.: Reactive intermediates revealed in secondary organic aerosol formation from isoprene, P. Natl. Acad. Sci., 107, 6640-6645, 2010.

Valverde-Canossa, J., Ganzeveld, L., Rappenglück, B., Steinbrecher, R., Klemm, O., Schuster, G., and Moortgat, G.: First measurements of $\mathrm{H}_{2} \mathrm{O}_{2}$ and organic peroxides surface fluxes by the relaxed eddy-accumulation technique, Atmos. Environ., 40, 55-67, 2006.

Vereecken, L., Müller, J.-F., and Peeters, J.: Low-volatility polyoxygenates in the $\mathrm{OH}$-initiated atmospheric oxidation of $\alpha$ pinene: Impact of non-traditional peroxyl radical chemistry, Phys. Chem. Chem. Phys., 9, 5241-5248, 2007.

Welz, O., Savee, J. D., Osborn, D. L., Vasu, S. S., Percival, C. J., Shallcross, D. E., and Taatjes, C. A.: Direct kinetic measurements of Criegee intermediate $\left(\mathrm{CH}_{2} \mathrm{OO}\right)$ formed by reaction of $\mathrm{CH}_{2} \mathrm{I}$ with $\mathrm{O}_{2}$, Science, 335, 204-207, doi:10.1126/science.1213229, 2012.

Wängberg, I., Barnes, I., and Becker, K. H.: Product and mechanistic study of the reaction of $\mathrm{NO}_{3}$ radicals with $\alpha$-pinene, Environ. Sci. Technol., 31, 2130-2135, doi:10.1021/es960958n, 1997.

Wolfe, G. M., Thornton, J. A., Yatavelli, R. L. N., McKay, M., Goldstein, A. H., LaFranchi, B., Min, K. E., and Cohen, R. C.: Eddy covariance fluxes of acyl peroxy nitrates (PAN, PPN and MPAN) above a ponderosa pine forest, Atmos. Chem. Phys., 9, 615-634, doi:10.5194/acp-9-615-2009, 2009.

Wolfe, G. M., Thornton, J. A., Bouvier-Brown, N. C., Goldstein, A. H., Park, J.-H., McKay, M., Matross, D. M., Mao, J., Brune, W. H., LaFranchi, B. W., Browne, E. C., Min, K.-E., Wooldridge, P. J., Cohen, R. C., Crounse, J. D., Faloona, I. C., Gilman, J. B., Kuster, W. C., de Gouw, J. A., Huisman, A., and Keutsch, F. N.: The Chemistry of Atmosphere-Forest Exchange (CAFE) Model - Part 2: Application to BEARPEX-2007 observations, Atmos. Chem. Phys., 11, 1269-1294, doi:10.5194/acp-11-12692011, 2011.

Wolfe, G. M., Crounse, J. D., Parrish, J. D., Clair, J. M. S., Beaver, M. R., Paulot, F., Yoon, T. P., Wennberg, P. O., and Keutsch, F. N.: Photolysis, $\mathrm{OH}$ reactivity and ozone reactivity of a proxy for isoprene-derived hydroperoxyenals (HPALDs), Phys. Chem. Chem. Phys., 14, 7276-7286, 2012.

Worton, D. R., Surratt, J. D., LaFranchi, B. W., Chan, A. W. H., Zhao, Y., Weber, R. J., Park, J.-H., Gilman, J. B., de Gouw, J., Park, C., Schade, G., Beaver, M., Clair, J. M. S., Crounse, J., Wennberg, P., Wolfe, G. M., Harrold, S., Thornton, J. A., Farmer, D. K., Docherty, K. S., Cubison, M. J., Jimenez, J.-L., Frossard, A. A., Russell, L. M., Kristensen, K., Glasius, M., Mao, J., Ren, X., Brune, W., Browne, E. C., Pusede, S. E., Cohen, R. C., Seinfeld, J. H., and Goldstein, A. H.: Observational insights into aerosol formation from isoprene, Environ. Sci. Technol., 47, 11403-11413, doi:10.1021/es4011064, 2013. 